\title{
Efeitos da configuração cavitária, técnica de inserção e modo de ativação na infiltração marginal de restaurações de resina composta
}

\section{Luisa Isabel Esmeral Leal}

Dissertação apresentada à Faculdade de Odontologia de Bauru, da Universidade de São Paulo, como parte dos requisitos para obtenção do título de Mestre em Odontologia, na área de Dentística.

(Edição Revisada) 


\section{Efeitos da configuração cavitária, técnica de inserção e modo de ativação na infiltração marginal de restaurações de resina composta}

\section{Luisa Isabel Esmeral Leal}

Dissertação apresentada à Faculdade de Odontologia de Bauru, da Universidade de São Paulo, como parte dos requisitos para obtenção do título de Mestre em Odontologia, na área de Dentística.

(Edição Revisada)

Orientador: Prof. Dr. Ricardo Marins de Carvalho 


\section{Luisa Isabel Esmeral Leal}

Nascimento:

Filiação:

1984-1990

1995

$1997-2000$

20 de maio de 1965, Popayán - Cauca - Colômbia.

Miguel Antonio Esmeral Cervantes.

Mary Leal Delgado de Esmeral.

Curso de graduação em Odontologia na Universidade Metropolitana de Barranquilla, Colômbia .

Professora colaboradora do curso de Odontologia da Universidade Metropolitana de Barranquilla Colômbia (disciplina de Anestesia).

Mestrado em Destística Operatória Dental Restauradora FOB - USP.

\section{Associações de classes e sociedades científicas}

Federación Odontológica Estudiantil Colombiana, desde 1984-1990.

Federación Odontológica Colombiana, Seccional Atlántico, desde 1991.

Asociación de Odontolológos Metropolitanos, desde 1991.

Cooperativa Médica del Valle - Barranquilla - Colômbia, desde 1992.

Associação dos Pós-graduandos FOB - USP, desde 1997.

International Association for Dental Research, desde 1999. 


\section{Dedicatoria}

Dedico este trabajo a mis tías, Denis e Isabel.

A ti tía "Chabe"

Gracias por enseñarme a creer en Dios y a confiar en él.

Gracias por todas la reuniones del colegio a las que tuviste que asistir.

Gracias por cuidarme cuando estuve enferma, cuando me cai y me ayudaste a levantarme, cuando estuve triste y me hiciste sonreir. Gracias por tu amor de madre.

Y a ti tía Denis:

Te agradezco todo el apoyo para emprender esta etapa, y gracias por quererme como tu hija.

Te agradezco todos los consejos y regaños que me enseñaron a ser una persona mejor.

Con todo mi amor "La Nena" 


\section{Agradecimiento Especial}

A mi padre Miguel: gracias por el ejemplo de hombre que eres, integro, sincero, práctico, honesto, responsable y por mostrarme con este ejemplo el camino correcto .

A mi madre Mary gracias por la vida, por el amor, el cariño, los sacrificios. Gracias mami por ser mi mamá.

Ao meu grande amor Osmael, obrigada pelo amor, apoio, companhia e compreensão.

A mi hermana María Alejandra, gracias "flaca" por ser mi amiga, complice y compañera.

A mis hermanos Miguel Carlos y Miguel E. gracias por el amor, la compañía, los consejos, los regaños y hasta por la discusiones. Pero en especial gracias por el apoyo en todos estos años.

A mis hermanos Jorge y Jaime gracias por el cariño, el respeto y todos los momentos convividos.

A mis abuelitas Mamá Licha y Alejandra (In Memoriam) gracias por el amor.

A mis cuñados Elvira, Amanda y Pedro gracias por el cariño y la compañía. Pero en especial gracias por querer a mis hermnaos y darme el placer de ser tía.

A todos mis sobrinos Stella y Stephane, Margarita, Tanya, María Angélica, Lizandro Luis, Lina María (mi ahijada) y Ricardo el recién nacido. gracias por hacerme la tía y madrina más feliz del mundo.

A todas mis tías y tíos gracias por el apoyo, cariño y todos estos años de convivencia. 
A todos mis primos y primas por la compañia, compañerismo, complicidad y en especial por el cariño. 


\title{
Minha Admiração, Respeito e Eterna Gratidão
}

\author{
Ao Prof. Dr. \\ Ricardo Marins de Carvalho
}

Obrigada por ser meu professor, meu orientador, meu conselheiro e meu amigo.

Aproveito para expressar-lhe, uma vez mais, meu carinho e gratidão.

Também quero fazê-los extensivos a toda sua família, em especial a seus pais e sua esposa Andrea. 


\section{Agradecimentos}

Ao Brasil e a todos os brasileiros por me acolherem tão bem e me fazerem sentir em casa.

À Universidade de São Paulo, Prefeitura do Campus, Bauru; ao Dr. Dagoberto, pela cortesia e carinho com o que sempre me recebeu.

À Faculdade de Odontologia de Bauru na pessoa de seu diretor Dr. Aymar, meu muito obrigada pelo carinho e prontidão para me ajudar.

À pós-graduação pela aceitação do meu nome no mestrado. Ao Dr. Pegoraro pelo carinho e brincadeiras, muito obrigada Professor. Ao Dr. Pereira obrigada pelo ensinamentos proferidos.

Aos funcionários da Pós-graduação: Aurélio, Ana, Débora, Cleusa e Heloísa, muita obrigada pela disponibilidade e pela sua grande ajuda. Em especial a minhas amigas Neide e Giane, obrigada pela amizade.

Ao departamento de Dentística, Endodontia e Materiais Dentários e a todos seus professores e funcionários pelo ensino e pelo convívio. 
Ao Departamento de Bioquímica, em especial, ao Ovídio e à Telma, pessoas que me concederam seu valioso tempo.

Ao Departamento de Anatomia, a todos os professores, em especial ao Dr. Navarro pela sua ajuda prestativa e gentileza dispensada. Aos funcionários, Cláudia, Michelli, Eugênia, e Romario obrigada pelo carinho e simpatia.

Aos Colegas do curso de Mestrado Lúcia, Margareth, Marcelo, Adriano, Rossana Cristiane, Maria Carme, Júlio, Lussara, , Roberta, Rodrigo, Sérgio, Juliano, Juliana, Mónica, Ana.

Aos colegas dos cursos de mestrado e doutorado nas outras áreas.

Aos funcionários da Biblioteca na pessoa da sua diretora D. Eliane pela gentileza, colaboração e prontidão com que atenderam às minhas necessidades. Jane, Vera, Vera Lúcia, Mônica, Valéria, Tâmara, D. Teresa, Denise, Cibéli, César, Marcelo e Ademir. Em especial à minha amiga Rita, e à tia Omersinda.

Aos guardas e porteiros da FOB, pela sua disponibilidade e ajuda sempre prestativa nos momentos mais difíceis desta pesquisa.

Ao CNPq., pela apoio financeiro, necessário para a realização deste programa de pós-graduação. 


\section{Meu Sincero Agradecimento}

À família Mondelli por me acolher em seu lar com carinho de família. A D. Marisa, Prof. José Mondelli, ao meu colega de curso de Mestrado e amigo, Adriano, ao Prof. Rafael e à sua lindíssima esposa, a todos vocês, meu muito obrigada .

A Prof. Dr. Mário Honorato e sua esposa Patrícia pela ajuda e amizade.

A o Prof. Dr. Alberto Consolaro pelo ensino e amizade. Muito obrigada Professor.

A mi primo Fabrizio mi única familia aquí en Bauru, gracias por tu ayuda incondicional y tu compañía, sin tu apoyo, hubiese sido imposible hacer realidad este sueño.

A Prof. a Lúcia, minha colega do curso de Mestrado, que se converteu em minha irmã brasileira, obrigada por tudo e também um muito obrigada pelo recebimento aconchegante em seu lar.

A Prof. ${ }^{a}$ Margareth, minha colega de turma do curso de Mestrado e amiga, quero expressar o meus sentimentos de carinho e amizade para você e sua família. 
À família Duarte: Paulinho, tia Alair, tio Geraldo, Mágda e Roberto pelo carinho, amizade e simpatia. Sempre os levarei no meu coração

Ao Marcelo uma pessoa prestativa demais, obrigada por toda tua ajuda e amizade.

Aos amigos, Valéria, Regina, Gislene, Adriano, Guadalupe, Dáni, German, Fabrício, Vanessa, Elaine, Mauricio, Meslisa, Fábio, Denise. Aos amigos hispano-americanos, Pablo, Sergio, Ana María, Papo, Patricia, Hair, Lizmara, Julio, Samira, Guillo, Mario, Rafita, Juan José.

À todos meus alunos, muito obrigada pela confiança e carinho. 


\section{Minha Admiração às Grandes Mulheres da FOB}

Prof. ${ }^{a}$ Dr. ${ }^{a}$ Maria Fidela, minha admiração e respeito pela grande luta num mundo de homens.

À Prof.a Dr. ${ }^{a}$ Ana Lúcia Capelozza obrigada pelo ensino, meu respeito e admiração pelas suas aulas show.

À Prof. ${ }^{a}$ Dr. a Teresa, pela amizade, carinho e pelo convívio.

À Prof.as Dr.as, Maria Francisca e Cidinha, pela gentileza com que sempre me trataram.

À Prof. a Denise da patologia, obrigada pelo carinho e amizade.

As Prof.as Odila da Microbiologia e Nilce da Saúde Coletiva pela sua gentileza.

A todas vocês, meu reconhecimento por terem sido profissionais, professoras, esposas e mães. Em uma palavra, terem-se destacado como mulheres. 


\section{Agradecimientos}

A Colombia mi lindo país

A la Universidad Metropolitana de Barranquilla, en especial a su Fundador Dr. Gabriel Acosta Bendeck, y a su Rector Dr. Eduardo Acosta Bendeck.

A mis queridos Profesores y amigos Dr. Jorge Coronell, Dr. Ferney Gonzales, Dr. Guzman, Dr. Luis Serrano, Dra. Olga de Arango, Dra. María Claudia, Dr. Willian Daza, Dr. Morron, Dr. Guillermo Jimenez

A mis colegas y amigos León, Liliana, Luis Fernando, Tatiana, Sarita, Robinson, Nicolás, Reynel, Luisa, José Luis, Jesús, Zoraida. Porque aunque lejos siempre me desearon suerte y me dejaron saber cuanto me aprecian a todos ustedes un abrazo enorme y un beso.

A la Asociación de Odontólogos Metropolitanos

A la Federación Odontológica Colombiana. 


\section{Sumario}

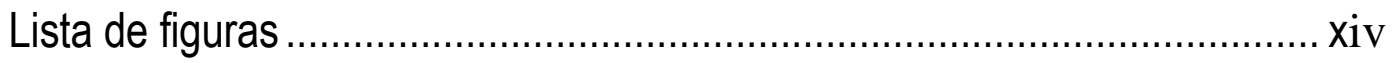

Lista de abreviaturas e símbolos ..............................................................

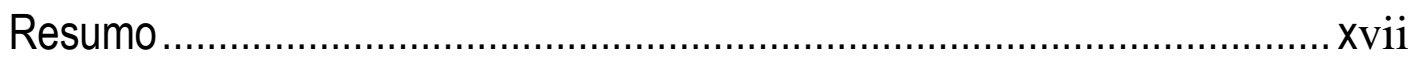

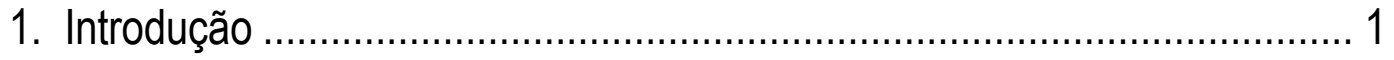

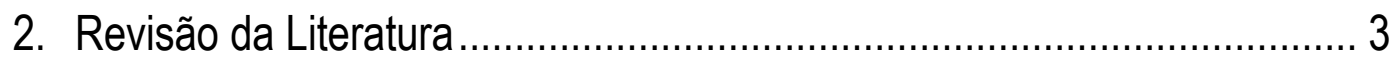

3. Proposição .................................................................................. 40

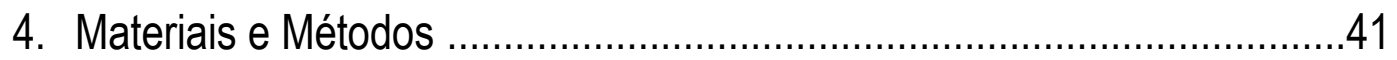

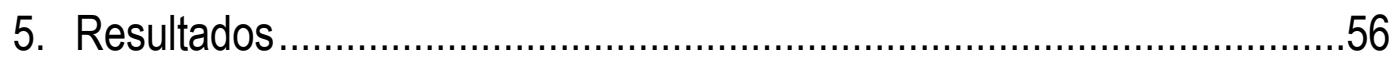

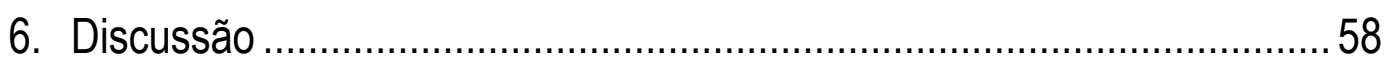

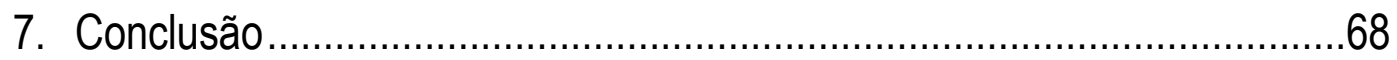

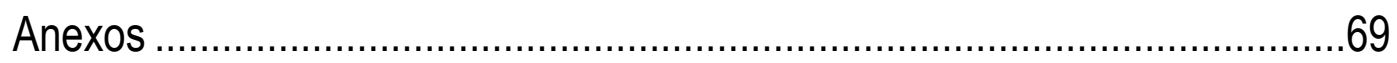

Referencias Bibliográficas .....................................................................

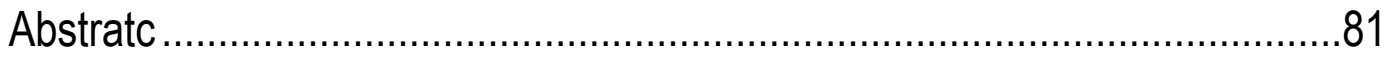




\section{Lista de Figuras}

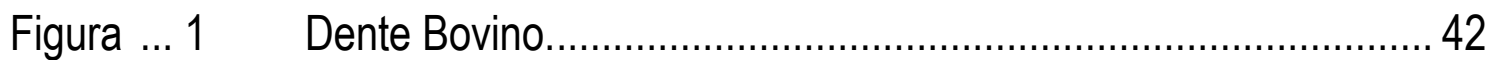

Figura 2 Corte do dente bovino na máquina de corte com 0 dispositivo de acrílico.

Figura 3 Dente bovino seccionado.

Figura 4 Preparos cavitários: A - Cavidade de $3 \mathrm{~mm}$ e B- cavidade de $6 \mathrm{~mm}$. 44

Figura 5 Condicionamento ácido. 45

Figura 6 Secagem da cavidade com papel absorvente. 46

Figura 7 Aplicação do sistema adesivo. 47

Figura 8 Superfície brilhante após da aplicação do adesivo. 47

Figura 9 Resina Bisfil 2B, Bisco. 48

Figura 10 Resina Z-100, 3M. 48

Figura 11 Quadro da divisão dos grupos de estudo, segundo o material empregado, dimensão das cavidades e técnica de restauração.

Figura 12 Acomodação do primeiro incremento da técnica incremental. ....51

Figura 13 Acomodação do segundo incremento da técnica incremental.....51

Figura 14 Dente protegido com esmalte de unhas. 53 
Figura 15 Secções dos espécimes......................................................... 54

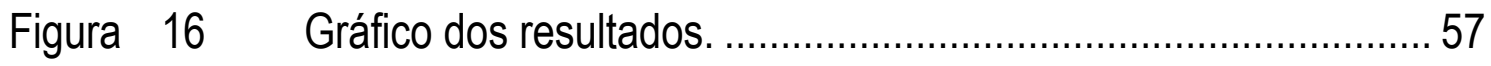

Figura 17 Esquema da configuração cavitária ..........................................61

Figura 18 Esquema da relação do modo de polimerização das resinas e contração de polimerização....................................................... 64 


\section{Lista de abreviaturas e símbolos}

$\begin{array}{ll}\text { EDTA }= & \text { Ácido Etileno Diamino Tetra-acético } \\ \mathrm{M}= & \text { Molar (unidade de medida química) } \\ \mathrm{mm}= & \text { milímetro } \\ \mathrm{mm}^{3}= & \text { milímetros cúbicos } \\ \mathrm{Mpa}= & \text { Mega Pascal } \\ \mathrm{mW} / \mathrm{cm}^{2}= & \text { miliWatts por centímetro quadrado } \\ \mathrm{N}^{0}= & \text { número } \\ { }^{\circ} \mathrm{C}= & \text { Grau Celsius (Centígrados) } \\ \mathrm{pH}= & \text { Potencial Hidrogeniônico } \\ \mathrm{X}= & \text { indica aumento em número de vezes } \\ \#= & \text { número } \\ \%= & \text { porcentagem } \\ \mu \mathrm{m}= & \text { micrômetro } \\ <= & \text { menor que (p/significância estatística) } \\ >= & \text { maior que (p/ significância estatística) } \\ \mathrm{s}= & \text { segundos } \\ \mathrm{MOD}= & \text { mesio-ocluso-distal } \\ \pm= & \text { mais ou menos }\end{array}$




\section{Resumo}

A configuração cavitária e o modo de polimerização das resinas compostas têm sido apontados como fatores que podem afetar a interface adesiva. Nesta pesquisa, investigamos a microinfiltração em cavidades de Classe $\mathrm{V}$, e para tanto foram realizadas cavidades de $6 \mathrm{~mm}(\mathrm{C}=6)$ ou $3 \mathrm{~mm}(\mathrm{C}=3)$ de comprimento, $3 \mathrm{~mm}$ de largura e 1,5 mm de profundidade, na face vestibular das raízes de incisivos bovinos. As cavidades, foram condicionadas com ácido fosfórico a $37 \%$, em gel $(3 \mathrm{M})$, foram tratadas com duas camadas de adesivo Single Bond (3M) e restauradas com resina composta Z-100 (3M) ou Bisfil-2B (Bisco), utilizando a técnica incremental ou a técnica de um único incremento. Os dentes restaurados foram armazenados em água destilada a $37^{\circ} \mathrm{C}$ durante 48 horas, protegidos com esmalte de unhas até $1 \mathrm{~mm}$ aquém das margens da restauração, imersos em fucsina básica a 0,5\% durante 4 horas e lavados em água corrente por uma hora. As restaurações foram secionadas em seu longo eixo e as seções foram digitalizadas em um scanner para determinar o grau de infiltração marginal em milímetros e analisa-las através de um programa de computação para análise de imagem. A seção com maior extensão de infiltração foi escolhida para análise dos resultados. $\mathrm{O}$ tamanho da amostra foi $\mathrm{N}=24$ e os resultados foram descritos em milímetros de infiltração.

\begin{tabular}{|c|c|c|c|} 
Cavidade & Z-100 & Z-100- & Bisfll-2B \\
& incremento único & \multicolumn{1}{c|}{ Incremental } & incremento único \\
\hline C 3 & $0.97 \pm 0.5^{\mathrm{a}}$ & ------ & $0.88 \pm 0.5^{\mathrm{a}}$ \\
\hline C 6 & $0.97 \pm 0.5^{\mathrm{a}}$ & $1.11 \pm 0.4^{\mathrm{a}}$ & $1.20 \pm 0.3^{\mathrm{a}}$ \\
\hline
\end{tabular}


A análise estatística foi realizada pelo teste de ANOVA e mostrou que não houve influência ou interação estatisticamente significante entre os fatores (p.> 0,05). Todas as técnicas mostraram algum grau de infiltração e não se identificaram diferenças estatisticamente significantes entre as paredes gengival e apical ( $p>0.05$ ). A microinfiltração não foi afetada pela configuração cavitária ou pelo modo de polimerização das resinas. 


\section{Introdução}

Durante os procedimentos restauradores, fatores como tamanho da cavidade, tratamento da superfície dentinária, tipo de sistema restaurador adesivo, técnica de aplicação e técnica de inserção do material podem afetar a integridade marginal das restaurações de resina composta ${ }^{1,21}$, sendo este último um fator fundamental na determinação da longevidade de restaurações ${ }^{2}$. As restaurações de resina composta são particularmente afetadas por fenômenos decorrentes de sua inevitável contração de polimerização. Quando suspensas em líquido, por exemplo, as resinas compostas contraem-se livremente, reduzindo seu volume original em cerca de 2 a 4\%, dependendo de sua composição. Quando inseridas em uma cavidade e associadas a técnicas adesivas, essa contração gera tensões que vão se concentrar nas interfaces adesivas dente/restauração, podendo causar ruptura da união ${ }^{24,34}$ e determinar 0 aparecimento da infiltração marginal. Os fenômenos da tensão na interface são afetados pelo Fator-C ou configuração cavitária e também pela cinética ou velocidade de polimerização, uma vez que as resinas fotopolimerizáveis contraem-se mais rapidamente que as autopolimerizáveis. O Fator-C, também denominado de fator de configuração cavitária,

é representado pela proporção entre a área de superfície aderida e a área de superfície livre de uma restauração e tem exercido grande influência na determinação das tensões geradas nas interfaces adesivas ${ }^{13,}{ }^{34}$. Acredita-se que quanto maior for essa proporção, maiores serão as tensões geradas nas interfaces adesivas, comprometendo a qualidade da união e do selamento marginal.

Se a integridade marginal é conseguida ou controlada durante e após a confecção da restauração, a infiltração marginal pode ainda ocorrer em função da deterioração química e estresses mecânicos ou térmicos, aos quais estará sujeita a longo prazo'. 
Recentemente, tem-se demonstrado que a cinética de polimerização da resina composta também pode determinar variações nas tensões de contração geradas na interface ${ }^{57,61}$. As resinas fotopolimerizáveis polimerizam-se mais rapidamente que as auto-polimerizáveis. Quanto mais rápida a polimerização, menor o tempo disponível para ocorrer o relaxamento da massa de resina, determinando, para as resinas fotopolimerizáveis, uma maior tensão de contração a ser transferida para a interface adesiva. Nas resinas auto-polimerizáveis, a polimerização ocorre mais lentamente, permitindo que o relaxamento compense, em parte, as tensões geradas nas interfaces ${ }^{13}$. A polimerização incremental tem sido apontada como um recurso operatório para reduzir as tensões de contração nas resinas fotopolimerizáveis ${ }^{45}$. Nessa técnica, a redução do volume de resina a ser polimerizado por incremento é também determinante na redução das tensões de contração geradas nas interfaces.

Diante do exposto, compreende-se que vários fatores determinam variações das tensões de contração de polimerização das resinas compostas inseridas em cavidades. 0 presente estudo objetiva verificar a influência da configuração cavitária e do modo de ativação da resina composta, na qualidade marginal de restaurações de resina composta. 


\section{Revisão Da Literatura}

Com a intenção de estudar a adaptação marginal de restaurações de resina composta, AL-HAMADANI e CRABB, em 1975, empregaram uma resina à base de metacrilato (Palakav, Kulzer) e duas resinas compostas (Adaptic, Johnson \& Johnson e Cosmic, A.D. International), para determinar a infiltração marginal em cavidades tratadas ou não com condicionamento prévio das paredes cavitárias. Restaurações de Classe V e II foram realizadas em 100 dentes, sendo que 40 foram restaurados com Palakav (Kulzer), 40 com Adaptic (Johnson \& Johnson) e 20 com Cosmic (A.D. International). Metade dos espécimes de cada grupo foi restaurada seguindo as indicações do fabricante e metade recebeu condicionamento prévio com ácido cítrico a $50 \%$, por 1 minuto. Os espécimes foram armazenados em solução fisiológica a $37^{\circ} \mathrm{C}$ por 24 horas e, em seguida, imersos por 72 horas em anilina azul a $2 \%$, a $37^{\circ} \mathrm{C}$. Após avaliação, os autores notaram que a penetração do corante e a presença de fendas, registradas pelo microscópio eletrônico, foram marcadamente maiores nas interfaces cervicais do que nas oclusais das cavidades de Classe V. Relataram ainda que as resinas compostas examinadas foram superiores com relação à adaptação marginal do que a resina a base de metacrilato.

Em 1975, ASMUSSEN relacionou a contração de polimerização com a composição das resinas compostas, investigando a largura máxima das fendas marginais ocorridas em restaurações realizadas em dentes humanos, empregando diversas marcas comerciais de resina composta. Uma correlação positiva entre a largura da fenda e a quantidade de monômero diluído foi encontrada. Quanto maior a quantidade de monômero diluído, menor a viscosidade e maior a contração volumétrica. A baixa viscosidade reduz o tamanho da fenda por facilitar o escoamento, embora a alta contração volumétrica possa aumentar o seu tamanho, demonstrando que a composição da fase orgânica é de 
importância primária para o controle da contração de polimerização. Os efeitos da contração não foram afetados pelo conteúdo da matriz inorgânica e muito menos pelo coeficiente de expansão térmica. Dessa forma, parece que as partículas das resinas compostas são de importância maior como agente de reforço e, em menor grau, garantem uma adequada adaptação marginal.

Em 1982, BAUSCH et al. estudaram a contração de polimerização de algumas resinas compostas e verificaram a influência de diversas variáveis sobre 0 seu desempenho. Explicaram que a contração de polimerização é o resultado da acomodação das moléculas em um espaço menor do que aquele requerido no estado líquido, onde as moléculas possuem certo grau de mobilidade. Após o início da reação de polimerização, acontece uma grande contração da massa ainda no estado plástico, que não tem tanta significância clínica como aquela que acontece a partir do início da geleificação. Nessa fase, o líquido viscoso torna-se um material rígido e a contração provoca tensões que só são compensadas pelo fluxo e escoamento do material. Quando a resina composta adere-se às paredes cavitárias vão existir duas possibilidades: ou ela se solta das paredes cavitárias, ou cede sem gerar tensão nas mesmas. Pode ainda existir uma situação intermediária, onde as tensões são geradas internamente no material. Quando a resina apresenta suficiente elasticidade, essas tensões podem ser compensadas pelo escoamento, porém, nas resinas com alto módulo de elasticidade, isto não ocorre, gerando degradação do material e formação de trincas ou rachaduras. Para finalizar, os autores concluíram que a contração de polimerização é um dos fatores mais importantes na longevidade das restaurações de resina composta.

Em 1983, GOLDMAN utilizou um dilatômetro para medir o volume da contração de polimerização de uma serie de materiais a base de resina. Os resultados foram apresentados em três grupos de acordo com o método de dispensar o material: pó/líquido (ativação química); pasta/pasta (ativação química) 
e materiais fotopolimerizáveis. Os resultados mostraram que o sistema pó/líquido apresentou a maior contração, os materiais fotopolimerizáveis apresentaram a menor contração e o sistema pasta/pasta mostrou resultados intermediários. Um experimento complementar foi realizado para examinar o efeito das bolhas de ar incorporadas no ato da mistura do material. A comparação das densidades, contração de polimerização e câmbios no volume por unidade de massa do material mostrou, que depois da mistura, a densidade diminuiu em cada material, porém, apresentaram um aumento significante na contração volumétrica e na contração por unidade de massa em três dos quatro materiais avaliados. As oportunidades para conseguir uma integridade marginal e induzir menos estresse dentro do material conseguem-se através de uma seleção correta do material, de modo que este tenha uma baixa contração de polimerização.

Em 1984, BAUER e HENSON estudaram o papel da microinfiltração na avaliação da integridade marginal de restaurações. A ocorrência da microinfiltração tem sido amplamente utilizada para avaliar o sucesso de um procedimento ou material restaurador. Existem fatores que favorecem a infiltração marginal afetando o desempenho clínico da restauração, tais como: presença de fendas interfaciais, propriedades físicas inadequadas do material (solubilidade, porosidade, contração e expansão térmica) e procedimentos restauradores impróprios. Clinicamente, os efeitos da microinfiltração manifestam-se através da hipersensibilidade dentinária, cárie secundária, descoloração marginal, penetração bacteriana, entre outros. Por outro lado, diferentes técnicas laboratoriais têm sido utilizadas para medir a extensão da microinfiltração e entre as mais empregadas estão: visualização (microscopia óptica ou eletrônica), traçadores, ar sobre pressão, penetração de corantes, isótopos radioativos e presença de bactérias ou cárie. A maioria dos métodos mencionados utiliza a ciclagem térmica, porque expõe as restaurações a situações clínicas simuladas, que normalmente criam estresse no selamento marginal, o que é particularmente importante quando o coeficiente de expansão 
térmica do material restaurador difere daquele da estrutura dentária. A microinfiltração pode proporcionar muita informação útil a respeito da performance dos materiais e procedimentos restauradores, e quando ela se apresenta como uma situação clínica, pode ser a origem de falhas das restaurações.

Em 1984, DAVIDSON e DE GEE investigaram o escoamento de duas resinas (Silar, 3M e Concise, 3M) durante a fase inicial de polimerização, na qual a maior quantidade de contração de polimerização é produzida. Os resultados mostraram que somente $12 \%$ (3,9Mpa) e 4\% (2,8Mpa), respectivamente para Silar (3M) e Concise (3M), das tensões que deveriam ser geradas durante uma contração livre foram registradas em condições restritas. Isso pode ser explicado pelo escoamento da resina. A contração que ocorre antes do momento da geleificação não tem sido reportada como de relevância clínica, entretanto, a contração rígida da fase pós-gel tem recebido muita atenção e sido apontada como responsável pelos defeitos marginais. No início da polimerização ocorre a máxima contração, mas o material ainda se encontra em fase de gel, as ligações cruzadas não estão completas e as moléculas podem acomodar-se melhor para resistir às tensões geradas pela contração. $O$ material atinge a rigidez em poucos minutos e ganha resistência, mas perde a capacidade de escoamento. Os autores concluíram que quando existe boa adesão às paredes cavitárias, o material escoa durante a polimerização (fase pré-gel) e a adaptação marginal pode ser mantida.

Em 1984, DAVIDSON; DE GEE e FEILZER estudaram a influência da contração de polimerização de resinas compostas auto e fotopolimerizáveis (Silux, 3M - fotopolimerizável e Silar, 3M - auto-polimerizável), na adesão a dentina (bovina) tratada com adesivos dentinários utilizando um tensilômetro. $O$ aumento na resistência adesiva foi medido em diferentes intervalos de tempo desde 0 começo da mistura dos materiais e foi comparado com o desenvolvimento do estresse durante todo o processo de polimerização. A adesão resistiu o estresse, 0 
que pode ser explicado pelo alívio do mesmo devido ao escoamento da resina. Em um estudo complementar, confeccionaram cavidades de Classe $\mathrm{V}$ em dentes bovinos, com a parede pulpar em dentina e a resina composta foi aderida a mais de duas paredes cavitárias. Nessa configuração, o escoamento é limitado e os valores da contração podem exceder a resistência de união e levar ao rompimento da adesão. Observaram infiltração em quase 100\% das paredes da dentina das cavidades restauradas e constataram que nas margens de esmalte somente $20 \%$ estavam infiltradas. Os valores de resistência de união foram superiores às tensões geradas durante a contração linear das resinas, que alcançaram valores de até de 2,4 Mpa. Quando a contração é restrita a uma direção (contração linear restrita), a adesão não é afetada, entretanto, em condições tridimensionais restritas (contração volumétrica restrita), não há adesão à dentina que possa suportá-la. Na prática clínica, a contração pode ser compensada pelo escoamento da resina, fato que ocorre com maior dificuldade nas cavidades de Classe I ou Classe V, onde só temos uma superfície livre e as tensões podem alcançar até $20 \mathrm{Mpa}$, dependendo da configuração cavitária. A força coesiva do material é maior e, portanto, falhas adesivas em dentina podem ocorrer. Os autores concluíram que devem ser desenvolvidas resinas compostas com menor contração de polimerização, juntamente com adesivos que permitam uma resistência de união superior às forças de contração de polimerização, além dos cuidados para criar formas cavitárias apropriadas para restaurações adesivas.

Em 1985, WELSH e HEMBREE avaliaram a microinfiltração marginal de restaurações de Classe V (lesões de abrasão e erosão simuladas) com 4 materiais restauradores para dentes anteriores (Concise, 3M); Fuji (G-C Dental Industrial Corp.); Den-Mat (Den-Mat ) e Clearfil (Kuraray). Os resultados desse estudo mostraram que houve maior infiltração marginal na margem gengival que estava em dentina e cemento do que na margem incisal localizada em esmalte. Dos 4 materiais, o Den-Mat (Den-Mat) foi o que mostrou a maior infiltração na margem 
gengival, no período de 1 semana, 3 meses e 6 meses. 0 Concise (3M) mostrou significante microinfiltração nos três intervalos de tempo, enquanto, que o Clearfil (Kuraray) apresentou microinfiltração inferior ao Concise (3M). Os resultados indicaram que seria precoce admitir um sistema restaurador de resina que não mostrasse infiltração marginal. 0 cimento de ionômero de vidro não mostrou microinfiltração significante em todos os intervalos de tempo.

Em 1986, DAVIDSON ressaltou a necessidade do emprego de uma técnica correta para obter boas restaurações de resina composta, enfatizando que a resistência à contração de polimerização é baixa em condições desfavoráveis, tais como em cavidades de Classe I, devido à adesão do material a todas as paredes cavitárias e às tensões geradas pela contração de polimerização as quais podem exceder a resistência adesiva da resina composta à estrutura dentária e determinar a ruptura da união. Felizmente, na prática, essas tensões podem ser aliviadas pelo escoamento da resina. As tensões geradas pela contração de polimerização têm uma relação diretamente proporcional à velocidade de polimerização. A configuração cavitária favorável é relevante para reduzir contração de polimerização e manter a adesão. Salientou que quanto mais paredes aderidas, mais alto o Fator-C, e vice-versa, sendo que um menor Fator- $\mathrm{C}$ produz menos efeitos adversos na adesão. Descreveu também uma técnica de inserção incremental para resinas fotopolimerizáveis, a qual parece ser vantajosa, desde que o primeiro incremento seja aderido a uma só parede cavitária, preferencialmente em dentina, para permitir o escoamento do material nesse sentido, permitindo melhor qualidade adesiva à esse substrato. 0 autor concluiu que existe uma interdependência entre as tensões geradas durante a contração de polimerização e a configuração cavitária.

LUTZ; KREJCI e OLDENBURG, em 1986, pesquisaram o conceito de que as resinas contraem-se em direção à fonte de luz e que a contração está 
diretamente relacionada com o volume do incremento. Objetivando uma melhor adaptação marginal, idealizaram uma nova técnica restauradora para as caixas proximais das cavidades, denominada de técnica de três incrementos. Nessa técnica, o primeiro incremento foi inserido no terço cervical da caixa proximal e fotopolimerizado através de uma cunha refletiva; o segundo foi colocado nos dois terços da parede vestibular da caixa proximal e fotopolimerizado através dessa mesma parede, e o terceiro incremento, de volume menor do que o segundo, foi colocado na parede lingual, através da qual foi fotopolimerizado. A caixa oclusal da cavidade foi restaurada e fotopolimerizada por oclusal. Os espécimens assim restaurados foram submetidos à ciclagem térmica e mecânica, as superfícies proximais foram analisadas com um microscópio e o selamento marginal avaliado através da medição da infiltração do corante nas margens cavitárias. Os autores concluíram que a nova técnica de inserção e fotopolimerização da resina apresentou um comportamento adequado, proporcionando um melhor selamento marginal e diminuindo a infiltração. Ressaltaram que futuros avanços da resistência adesiva na resina composta a esmalte ou dentina não resolverão 0 problema de adaptação marginal, porque as tensões geradas pela contração de polimerização da resina composta pode, em muitos casos, superar as forças de união dos tecidos duros. Os autores comentaram também que é responsabilidade do cirurgião-dentista tentar superar as propriedades desfavoráveis dos materiais atuais, através do uso de técnicas e procedimentos sofisticados.

Em 1987, FEILZER; DE GEE e DAVIDSON estudaram a influência da configuração cavitária na geração do estresse de contração de polimerização em restaurações de resina composta associadas a um adesivo dentinário. Confeccionaram restaurações cilíndricas posicionadas entre dois discos de metal e a configuração cavitária foi simulada por variações nas dimensões desses cilindros. O Fator-C foi obtido através de cálculos e reproduzido nessas restaurações simuladas mediante a variação na distância entre os discos de metal. 
Os autores empregaram as resinas auto-polimerizáveis Silar (3M) e P-10 (3M) e determinaram o estresse gerado pela contração de polimerização para cada um dos fatores de configuração cavitária e para os diversos volumes dos espécimes. Os resultados mostraram que quando o Fator- $C$ foi menor ou igual a 1,0 relaxamento pelo escoamento foi capaz de manter a integridade marginal; quando o Fator-C estava entre 1 e 2, foram observadas falhas coesivas em alguns espécimes, e quando o Fator-C foi maior que 2, todas as falhas foram coesivas, mostrando que a configuração cavitária é relevante para a clínica, e que 0 alívio do estresse pelo escoamento não é suficiente para preservar a adesão à dentina pelos adesivos dentinários. Em geral, a contração de polimerização é dependente da configuração cavitária ou Fator-C e independente do volume da restauração.

Em 1987, HASSAN et al. idealizaram uma técnica de inserção em incrementos para cavidades de Classe II, na qual o primeiro incremento deveria ser colocado em íntimo contato com a matriz metálica, desde a parede gengival até a face oclusal da restauração, promovendo uma superfície uniforme e forma de contorno em direção ocluso-gengival e linguo-bucal, evitando desta forma a solução de continuidade dos próximos incrementos horizontais. 0 autor concluiu que essa técnica de inserção produz um contorno interproximal adequado porque a face proximal é construída inteira durante a colocação do primeiro incremento. A contração de polimerização acontece ao longo da superfície proximal sem os efeitos de camadas, obtendo-se um ótimo contato proximal.

Em 1988, FEILZER; DE GEE e DAVIDSON pesquisaram 0 desenvolvimento de uma contração de polimerização livre em 26 resinas compostas (fotopolimerizáveis e auto-polimerizáveis) e 2 ionômeros de vidro, medindo 0 volume de contração de polimerização com um dilatômetro modificado, em intervalos de tempo de 1, 5 e 30 minutos e de 1, 12 e 24 horas. Os cimentos de ionômeros de vidro demostraram um desenvolvimento de contração mais lento 
quando comparados às resinas compostas. Nos 10 minutos iniciais da reação de presa, ocorreu uma contração de cerca de 40 a $50 \%$ no volume dos cimentos que permaneceram maleáveis durante esse período, permitindo que uma certa acomodação molecular ocorresse durante a formação das ligações químicas. As resinas, entretanto, demostraram um valor muito alto de contração.

A literatura aponta evidencias de que a contração de polimerização pode produzir uma diminuição na largura vestibulo-lingual de cavidades em dentes posteriores restaurados com resina composta. Em 1988, SMITH e CAUGHMAN propuseram-se a avaliar a magnitude desses efeitos com diferentes técnicas restauradoras. Foram confeccionadas cavidades de $1 \mathrm{~mm}$ de profundidade para a colocação de pinos nas cúspides, de 24 pré-molares superiores, nas quais se prepararam cavidades de 2,5 $\mathrm{mm}$ de profundidade (MOD) e 2,0 $\mathrm{mm}$ de largura. Os dentes foram restaurados de acordo com os grupos: grupo I, a resina composta (oclusal) foi inserida em um único incremento e fotopolimerizada por 120s; no grupo II, a resina foi inserida em 3 incrementos iguais e fotopolimerizada por 40s cada; e no grupo III, colocou-se uma base de cimento de ionômero de vidro e restaurou-se como no grupo II. Os resultados indicaram que a distância média entre os pinos diminuiu $24 \mu \mathrm{m}$ para o grupo I, $13 \mu \mathrm{m}$ para o grupo II e $10 \mu \mathrm{m}$ para 0 grupo III. Concluíram os autores que a distância intercuspídea das cavidades MOD foi reduzida quando foram restauradas com resinas compostas. Houve menor redução de distância quando se utilizou a técnica incremental e as restaurações com base de cimento de ionômero de vidro apresentaram menor quantidade de alterações dimensionais na distância intercuspídea.

Em 1989, CRIM comparou a compatibilidade de algumas resinas compostas com o sistema adesivo Scotchbond Dual Cure (3M) e pesquisou a influência do tipo de resina composta na microinfiltração marginal de restaurações realizadas com cinco sistemas adesivos e 6 resinas compostas. Não foram 
encontradas diferenças estatisticamente significantes entre os valores de microinfiltração quando as resinas compostas foram empregadas com seus próprios adesivos e também não se observaram diferenças estatisticamente significantes entre as resinas compostas quando o Scotchbond Dual Cure (3M) foi empregado como adesivo. Ocorreu severa infiltração na margem gengival em dentina em todas as restaurações, embora a infiltração tenha sido reduzida quando se utilizou a resina composta de micropartículas Silux (3M), com menor viscosidade, associada ou não a vários agentes adesivos. A conclusão deste estudo é que a alta viscosidade e os baixos valores da sorpção de água de algumas resinas compostas podem influenciar adversamente a microinfiltração, independentemente dos sistemas adesivos utilizados.

Em 1989, EICK e WELCH determinaram o efeito da técnica de inserção sobre a contração de polimerização nas restaurações de resina composta, utilizando a técnica de incremento único e duas técnicas incrementais. Na técnica incremental tradicional, a resina foi colocada desde a superfície gengival até a oclusal em incrementos horizontais. Na segunda técnica incremental, a resina foi aplicada primeiramente à superfície bucal ou lingual. Os autores testaram a hipótese de que não existe diferença estatisticamente significante na quantidade de contração de polimerização, número de trincas ou rachaduras, ou bolhas de ar na resina composta na interface dente/restauração, e que esses fatores são independentes da técnica de inserção utilizada. Os resultados foram analisados através de microscopia eletrônica. Quando se utilizou a técnica incremental tradicional (horizontal), houve excelente contato na parede gengival, embora as superfícies bucal e lingual se apresentassem com trincas ou rachaduras, tanto em esmalte como em dentina. Quando se utilizou a segunda técnica incremental, com a resina aderida as paredes bucal ou lingual, gerou-se a melhor adaptação e a menor quantidade de contração de polimerização que em qualquer uma das três técnicas utilizadas. Diante desses fatos, os autores concluíram que para minimizar, 
e possivelmente eliminar, a sensibilidade pós-operatória nas restaurações de resina composta em dentes posteriores, é necessária a aplicação correta de um adesivo dentinário, colocação do material em finas camadas, o esmalte deve ser biselado e condicionado e utilizar-se da técnica incremental onde a resina é aplicada nas paredes bucal ou lingual. Os autores acreditam que tomando esses cuidados no momento de fazer restaurações de resina composta em dentes posteriores, a sensibilidade pós-operatória poderá ser diminuída.

Em 1989, FEILZER; DE GEE e DAVIDSON verificaram a influência de distâncias entre as paredes opostas, na contração de parede a parede de diferentes sistemas restauradores adesivos. Os autores mediram a tensão de contração gerada nas interfaces opostas e verificaram que a redução da distância entre elas aumentava significantemente as tensões de ruptura.

Em 1989, KOENIGSBERG, FUKS e GRAJOWER compararam a infiltração marginal nas margens oclusais e cervicais das restaurações de resina composta realizadas com diferentes técnicas de inserção incremental (gengivo-oclusal e buco-lingual); com a infiltração obtida na técnica de restauração em um único incremento. Os resultados obtidos mostraram menor infiltração nas margens oclusais para todas as técnicas de restauração. 0 grau de penetração do corante na margem cervical decresceu com a utilização da técnica incremental. Não se apresentaram diferenças estatisticamente significantes entre as técnicas de inserção por incrementos.

Em 1990, ARAÚJO e ASMUSSEN investigaram o efeito de dois adesivos comerciais (Scotchbond 2, 3M e Tenure, Den-Mat), e duas modificações do sistema Gluma (Bayer AG, FRG), na adaptação de duas resinas compostas para dentes posteriores. Em dentes humanos, prepararam cavidades que foram restauradas com resinas fotpolimerizáveis (P-50, 3M e Estilux Posterior-L, Kulzer), utilizando a técnica de polimerização através das paredes cavitárias ao nível da 
superfície do esmalte. A contração de polimerização foi medida e apresentada como uma contração linear no nível da dentina. Esta contração linear variou de $0,66 \%$ no grupo controle, onde só resina foi aplicada, a $0,28 \%$ no grupo em que as cavidades foram tratadas com adesivos dentinários. Não se apresentaram diferenças entre os adesivos dentinários ou entre estes e 0 adesivo ao esmalte. Os autores recomendaram adiar o polimento da área marginal até o selamento das fendas marginais através da expansão higroscópica e 0 uso de selantes de superficie.

Em um estudo "in vitro", em 1990, ARAÚJO, SILVA FILHO e MENDES verificaram a infiltração marginal cervical em restaurações de Classe II variando 0 tipo de resina composta auto-polimerizável P-10 (3M) e resina fotopolimerizável P-30 (3M); o tipo de cavidade (convencional, com as seguintes dimensões: caixa oclusal: profundidade ocluso-pulpar $1,5 \mathrm{~mm}$; distância mésio-distal $2 \mathrm{~mm}$; distância vestíbulo-lingual $2 \mathrm{~mm}$ e caixa proximal: profundidade ocluso-cervical $3 \mathrm{~mm}$; distância mésio-distal $1 \mathrm{~mm}$; distância vestíbulo-lingual $2 \mathrm{~mm}$; e cavidade adesiva, com as seguintes dimensões: caixa oclusal: profundidade ocluso-pulpar $1,5 \mathrm{~mm}$; distância mésio-distal e vestíbulo-lingual do tamanho da broca esférica nº3; e caixa proximal: profundidade ocluso-cervical $3 \mathrm{~mm}$; distância mésio-distal e vestíbulo-lingual do tamanho da broca esférica $n^{0} 3$ ); e o tipo de tratamento do ângulo cavo-superficial com condicionamento ácido e sem condicionamento ácido. Verificou-se também o efeito da aplicação do adesivo dentinário Scotchbond (3M) em todos os grupos. A infiltração foi analisada por meio do corante Rodamina B, após ciclagem térmica entre as temperaturas de $10^{\circ} \mathrm{C}$ e $50^{\circ} \mathrm{C}$. Os resultados revelaram que não houve diferença estatística de infiltração marginal entre os dois materiais, porém, observou-se infiltração marginal cervical em todas as restaurações. Os autores concluíram que o emprego do condicionamento ácido mais o adesivo reduziram de $70 \%$ para $55 \%$ o grau de infiltração, e que 0 condicionamento ácido mostrou-se mais efetivo na redução da microinfiltração 
quando se usou resina fotopolimerizável. A ocorrência de infiltração cervical foi de $77,5 \%$ para as cavidades convencionais e 47,5\% para as adesivas, deduzindo-se que a redução no formato da cavidade promove uma redução da contração das resinas, pelo menor volume de material nela inserido.

Em 1990, CHEUNG revisou técnicas clínicas e materiais que têm sido sugeridos, e que estão disponíveis, para promover margens de ótima qualidade em restaurações de resina composta, referindo-se especialmente a restaurações em dentes posteriores. A pobre adaptação marginal e a microinfiltração são atribuídas à contração de polimerização das resinas compostas, podendo afetar 0 prognóstico de restaurações de resina composta em dentes posteriores. Com a introdução do ataque ácido, o problema de infiltração marginal nas margens de esmalte foi amplamente resolvido, entretanto, a adesão de resina composta à dentina ainda se apresenta problemático, pois as forças de união não são resistentes às forças de contração de polimerização, causando o rompimento da interface adesiva. Para tentar diminuir esses efeitos adversos da contração de polimerização, empregam-se mudanças no desenho da cavidade as quais passaram de cavidade convencional ou cavidade de Classe II para amálgama, que era a utilizada para restaurações de resina composta, para cavidades adesivas, nas quais o preparo cavitário se limita a eliminação do tecido cariado, confecção do bisel e arredondamento dos ângulos internos, ou seja, a dimensão da cavidade é então limitada quase que ao tamanho da broca; técnicas de inserção por incrementos e selantes de superfícies. Entretanto, o autor considera que falta muito a se pesquisar para se conseguir desenvolver uma resina composta que não sofra contração de polimerização, eliminado os problemas decorrentes dessa.

Em 1990, CHOHAYEB et al. estudaram alguns fatores que influenciam a microinfiltração. Utilizaram os sistemas restauradores adesivos Tenure (Den-Mat Corp.), Gluma (Colombus Dental), Scotchbond II (3M), e um adesivo experimental 
a base de oxalato férrico (dentina/esmalte). Confeccionaram cavidades de Classe V expulsivas em 40 dentes humanos e os restauraram com resina Silux (3M), fazendo termociclagem durante 7 dias entre as temperatura de $5^{\circ} \mathrm{C}$ e $55^{\circ} \mathrm{C}$ e submetendo-os, posteriormente, a coloração com nitrato de prata. A microinfiltração foi medida por escores, por três avaliadores independentes. As restaurações foram fotografadas e as imagens digitalizadas para determinar a presença ou não de excessos gengivais e acúmulos de adesivo, e para catalogar o volume da restauração como pequena, média ou grande. A microinfiltração foi menor quando houve excessos gengivais em todos os 4 adesivos testados. A presença de acúmulo de adesivo resultou em um aumento da microinfiltração, ao contrário da aplicação de camadas finas de adesivos. Também foi menor a microinfiltração quando o volume da restauração decrescia, para todos os sistemas. Existe uma correlação positiva entre microinfiltração e ausência de excessos gengivais, presença de acúmulos de adesivos, e volume da restauração.

Em 1990, EAKLE e ITO compararam os efeitos de diferentes técnicas de inserção por incrementos na extensão da microinfiltração nas margens de restaurações mesio-ocluso-distais (MOD) de resina composta. Utilizaram quarenta molares humanos inferiores, livres de cárie e de linhas de fratura, nos quais foram confeccionadas cavidades padronizadas de Classe II, e restauradas com resina composta (Herculite, Kerr), segundo os seguintes grupos: 1) incremento único; 2) técnica incremental, sendo dois incrementos horizontais na caixa proximal e um incremento na caixa oclusal; 3) se utilizou técnica incremental, sendo dois incrementos diagonais na caixa proximal e um horizontal na caixa oclusal, e grupo 4) também se utilizou a técnica incremental como no grupo 3 , adicionando-se uma camada de cimento de ionômero de vidro nas paredes gengival e axial, sem aplicação do ácido poliacrílico. A técnica incremental utilizada no grupo 3 produziu a menor infiltração marginal nas margens cervicais em esmalte, mas essa 
microinfiltração não teve uma diferença estatisticamente significante da observada na técnica de um único incremento utilizada no grupo 1. A camada de cimento de ionômero de vidro não foi capaz de prevenir microinfiltração quando a dentina não recebeu tratamento com o ácido poliacrílico. A adesão do cimento de ionômero de vidro a dentina sem tratamento não é tão forte para suportar as forças de contração de polimerização da resina composta. Nenhuma das técnicas de inserção foi capaz de prevenir uma extensa microinfiltração na margem cervical nas raízes dos dentes. Os autores concluem que outras técnicas com a intenção de prevenir a microinfiltração nas margens de resina composta precisam ser pesquisadas.

Em 1990, NEIVA et al. compararam a infiltração marginal de restaurações de resina composta fotopolimerizável com diferentes técnicas de inserção e fotopolimerização. Realizaram cinco grupos 1) técnica de um único incremento, 2) técnica incremental horizontal, 3) técnica incremental diagonal, 4) técnica incremental horizontal com polimerização com um cone (Collimator) e, 5) técnica incremental diagonal com polimerização através de cunha refletiva e matriz transparente. Os resultados obtidos não mostraram diferenças estatisticamente significantes em nenhuma das técnicas de inserção ou fotopolimerização em esmalte. A infiltração marginal em cemento foi menor no grupo 4, restaurado com técnica de inserção diagonal e polimerização através do cone (Collimator), entretanto, o grupo 5, restaurado com técnica incremental e polimerizado através de cunha refletiva e matriz transparente apresentou maior infiltração.

Em 1991, BERTOLOTTI descreveu, como solução para a redução do estresse de contração de polimerização, a técnica da contração direcionada. Seu objetivo foi direcionar a contração para a estrutura dentária e não para o centro da massa do material. 0 direcionamento dessa contração seria conseguido preenchendo dois terços da caixa proximal, de gengival para oclusal (até o limite amelodentinário), com resina auto-polimerizável. A técnica de inserção 
incremental de materiais restauradores com a finalidade de induzir a polimerização em direção à interface dente/restauração é recomendável. Afirmou que as resinas fotopolimerizáveis polimerizam-se primeiramente na superfície oclusal da restauração, gerando tensões nas margens e polimerizando-se para 0 centro da massa, posteriormente. Ao contrário, as resinas auto-polimerizáveis polimerizam-se inicialmente nas áreas mais profundas, pois a polimerização é acelerada pela temperatura e inibida pela presença de oxigênio. Portanto, nessas resinas, o progresso da polimerização atrai 0 material para a periferia da restauração. Após o preparo da cavidade, fez-se o condicionamento ácido de esmalte e dentina e aplicou-se o agente de união com polimerização e inserção da resina auto-polimerizável aproximadamente até a junção amelo-dentinária. Antes mesmo de completada a polimerização dessa resina, uma pequena camada de resina fotopolimerizável foi inserida, completando a restauração e, então, foi realizada a fotopolimerização. A técnica descrita pelo autor combina as vantagens da resina composta auto-polimerizável, ao ser inserida na porção interna da cavidade, com as vantagens da resina composta fotopolimerizável. 0 autor concluiu que tal técnica é indicada para cavidades pequenas e médias, e para cavidades Classe II não muito extensas. Com o direcionamento da contração de polimerização das resinas às paredes cavitárias, pode-se obter uma restauração de resina composta com melhor adaptação marginal e mínima sensibilidade pósoperatória.

Em 1991, CRIM examinou, através da microinfiltração, o efeito de três técnicas de restauração associadas a 4 sistemas adesivos da nova geração, enfatizando o estudo do efeito da técnica de inserção da resina composta. Confeccionou cavidades de Classe $\mathrm{V}$ que se estendiam além da união cemento/esmalte de dentes humanos. As técnicas de restauração foram: 1) incremental, com colocação do primeiro incremento na parede oclusal, estendendo-se abaixo do ângulo gengivo-axial 2) incremental, com inserção do 
primeiro incremento na parede gengival e, 3) técnica de um único incremento. Os dentes restaurados foram armazenados em água durante 24 horas e depois receberam estresse térmico (100 ciclos). A infiltração marginal foi calculada medindo a penetração linear da solução corante (solução de fucsina básica a 0,5\%). A penetração do corante foi minimizada pelo uso da técnica incremental, na qual o primeiro incremento foi colocado na porção coronal da cavidade e 0 segundo incremento foi colocado para preencher o restante da cavidade. Houve uma melhora na performance dos quatro adesivos e não houve diferenças estatisticamente significantes na microinfiltração dos materiais restauradores quando eles foram colocados com a técnica incremental.

Em 1991, ERICSON e DÉRAND estudaram um método de polimerização para reduzir a formação de fendas marginais cervicais, produzidas pela contração de polimerização das resinas compostas, em pré-molares humanos e em troqueis metálicos, nos quais foram confeccionadas cavidades de Classe II. Em uma das caixas proximais realizavam a polimerização através da transmissão de luz dentro da resina por meio de um cone transparente acoplado a fonte de luz, o qual foi pressionado na resina. As cavidades foram restauradas com três resinas compostas fotopolimerizáveis (Durafill, Kulzer; Oclusin, Imperial Chemical Industries; e Heliomolar, Vivadent). O grupo controle foi restaurado com técnica de dois incrementos horizontais. Em todas as cavidades onde foi empregado o cone, as fendas originadas na interface foram de aproximadamente $10 \mu \mathrm{m}( \pm 10.60)$, e nas restaurações do grupo controle de $109.5 \mu \mathrm{m}$ ( \pm 46.5$)$. A formação de fendas marginais, quando empregado o mesmo tipo de polimerização, foi sempre menor nas cavidades metálicas do que nas realizadas em dentes humanos.

Em 1991, ESPINOSA estudou a influência da contração de polimerização de resina composta, associada a algumas variáveis, sobre a capacidade de vedamento de restaurações mistas de Classe V. Vinte molares extraídos foram 
selecionados para receber cavidades de Classes V nas faces vestibular e lingual, apresentando a margem oclusal em esmalte e a margem cervical em dentina e/ou cemento. As restaurações foram realizadas com uma resina de micropartículas (Silux Plus, 3M), um adesivo dentinário (Scotchbond 2, 3M) e um cimento de ionômero de vidro fotopolimerizável (Vitrabond, 3M). Assim, sete grupos de seis cavidades foram restaurados, sendo que um grupo foi restaurado só com ionômero de vidro, quatro grupos sofreram tratamentos diferentes da superfície do cimento ionomérico, um grupo recebeu modificação no desenho cavitário e um grupo foi submetido à ciclagem térmica, a temperaturas entre $5^{\circ} \mathrm{C}$ e $55^{\circ} \mathrm{C}$. Após a realização desses procedimentos, os dentes foram imersos em solução de fucsina básica a $2 \%$ durante 24 horas, lavados e seccionados, com a finalidade de verificar o grau de infiltração através de microscopia óptica. Os graus de infiltração foram atribuídos seguindo o critério de escores diversos, para a margem de esmalte, dentina e a interface resina composta/ionômero de vidro. Os resultados demonstraram que as restaurações mistas foram superiores em relação ao selamento marginal, sendo que a diferença foi estatisticamente significante para ambas as margens. A microinfiltração nas restaurações mistas foi menos freqüente nas margens de esmalte do que em dentina. Os tratamentos realizados sobre a superfície do cimento ionomérico, a modificação do desenho cavitário e a ciclagem térmica não modificaram a intensidade da microinfiltração.

Nesse mesmo ano, PASCOTTO avaliou algumas técnicas restauradoras na redução da infiltração marginal em dentes posteriores, restaurados com materiais estéticos. Cinqüenta e seis pré-molares humanos extraídos receberam cavidades de Classe II MOD, com a parede gengival de uma das caixas proximais localizadas em esmalte e a outra em cemento. As técnicas utilizadas para restaurar as cavidades foram: restaurações diretas pela técnica incremental (P-50 $3 \mathrm{M}$ ), incrustações de resina composta (pelas técnicas direta e indireta, submetidas ou não à suplementação da polimerização) e de porcelana, (P-50, 3M; Sistema 
extra-oral EOS, Vivadent,; Inlay Kulzer, Kulzer e Fortune, Williams). Concluídas as restaurações, os dentes foram submetidos à ciclagem térmica durante oito dias em saliva artificial, variando a temperatura entre 5 e $55^{\circ} \mathrm{C}$, sendo que nos últimos ciclos foi utilizada a fluoresceina sódica em solução aquosa a $2 \%$ como agente traçador. A avaliação foi realizada por dois examinadores, através de diapositivos obtidos utilizando-se uma câmera fotográfica acoplada a um microscópio de fluorescência, concluindo que: 1- Todas as técnicas restauradoras foram incapazes de bloquear totalmente a infiltração marginal nas margens de esmalte ou cemento. 2- Não houve diferença estatisticamente significante na infiltração marginal ocorrida entre os sistemas restauradores para as margens de esmalte; 3A técnica de confecção de incrustações com o sistema Fortune (Williams) apresentou significantemente menor infiltração marginal nas margens de cemento $(p<0,05)$, quando comparada com a técnica incremental direta (Sistema Scotchbond 2, 3M / P-50 3M) e com a técnica de confecção de incrustações com 0 Sistema EOS, (Vivadent); 4- A suplementação da polimerização pelo sistema de luz ou calor não reduziu significantemente a infiltração marginal nas incrustações de resina composta; 5- A comparação da infiltração nas margens de esmalte com relação às de cemento, mostrou haver uma maior penetração do corante nas margens localizadas abaixo da união cemento/esmalte, com exceção das incrustações realizadas pela técnica indireta, com suplementação da polimerização (Scotchbond, 3M/Cement Dual, Vivadent /P-50, 3M), onde a diferença não foi estatisticamente significante e 6- Não houve diferença estatisticamente significante quanto ao vedamento marginal proporcionado pela técnicas direta e indireta de confecção de incrustações de resina composta.

Em 1991, SILVA e SOUZA Jr. et al. avaliaram a capacidade de vedamento marginal de 5 sistemas adesivos restauradores existentes no mercado. Foram empregados 40 dentes recém-extraídos por razões ortodônticas. Foram preparadas cavidades Classe II MOD com margens da parede gengival 
localizadas $2 \mathrm{~mm}$ acima do limite cemento/esmalte ou $2 \mathrm{~mm}$ abaixo desse limite e restauradas com os sistemas ARM (Johnson \& Johnson)/ Adaptic (Johnson \& Johnson) utilizando a técnica de um único incremento, Gluma (Bayer Dental)/ Lumifor (Bayer Dental ), Bondilite (kerr ) / Herculite (kerr), Scotchbond (3M) / P-30 (3M), e Glass lonomer Liner (3M ) /Scocthbond (3M) / P-30 (3M) utilizando a técnica incremental. Os espécimes foram submetidos durante 1 semana a 105 ciclos térmicos $\left(5^{\circ} \mathrm{C}\right.$ a $\left.55^{\circ} \mathrm{C}\right)$ e imersos em saliva artificial previamente corada com rodamina-B a $0,1 \%$ para determinação do selamento marginal. Em relação às margens de esmalte, os resultados mostraram melhor desempenho quando se empregava o sistema ionômero de vidro / Scotchbond (3M) / P-30 (3M), Scotchbond (3M) / P-30 (3M) e Bondlite (Kerr) / Herculite (Kerr), quando comparadas com Gluma (Bayer Dental ) / Lumifor (Bayer Dental ). Para as margens de cemento, a eficácia mais acentuada foi para o ionômero de vidro / Scotchbond (3M) / P-30 (3M), quando comparado com os sistemas ARM (Johnson \& Johnson) / Adaptic (Johnson \& Johnson) e Gluma (Bayer Dental) / Lumifor (Bayer Dental). Independentemente do sistema restaurador adesivo, houve mais infiltração marginal nas margens de cemento.

Em 1992, FUSAYAMA discutiu as indicações da resina auto-polimerizável ou fotopolimerizável. Esses dois tipos de resinas têm vantagens e desvantagens biológicas. A diferença entre as resinas auto-polimerizáveis e as resinas fotopolimerizáveis é que estas últimas têm uma grande tendência de se separar das paredes e das margens cavitárias. Métodos alternativos de inserção, como técnica incremental e bases de cimento, têm diminuído essa tendência, mas não tem solucionado o problema completamente. As resinas fotopolimerizáveis também podem fraturar a margem de esmalte friável, fato que não acontece com as resinas auto-polimerizáveis, porém, isto pode ser resolvido com a utilização de biséis. Um outro aspecto são as restaurações vestibulares, onde a estabilidade e a variedade da cor são muito importantes, e onde uma melhor performance está 
associada com as resinas fotopolimerizáveis. Já nas restaurações oclusais, um ponto importante é a resistência ao desgaste. Assim, o autor conclui que as resinas fotopolimerizáveis são melhor indicadas em restaurações vestibulares, enquanto que as auto-polimerizáveis estão melhor indicadas para restaurar cavidades profundas que tenham margens em dentina e em restaurações oclusais.

Em 1993, FEILZER; DE GEE e DAVIDSON estudaram o desenvolvimento do estresse de polimerização em resinas fotopolimerizáveis (Silux Plus, 3M e P-30, $3 \mathrm{M})$, com e sem inclusão de porosidade, em relação ao fator de configuração cavitária e compararam esses dados com os obtidos nas recentes pesquisas das resinas auto-polimerizáveis. A resina foi inserida entre dois discos de vidro, formando um cilindro de acordo com a circunferência dos discos e cujas superfícies foram silanizadas e fotopolimerizadas. Esses discos eram acoplados a um dispositivo especial e a um tensilômetro. 0 estresse gerado pela contração de polimerização foi determinado para diferentes fatores cavitários e seu correspondente em volume. Foram medidas as mudanças na distância entre os discos causadas pela contração de polimerização ou pela alteração térmica, em períodos de 30 minutos. Quando as medidas excediam um Fator- $\mathrm{C}=2$, observavase uma falha coesiva do material na interface vidro-material. Para valores de contração superiores a $17 \mathrm{Mpa}$, observavam-se falhas coesivas nos discos de vidro, não sendo possível determinar o valor da falha coesiva da resina P-30 (3M). 0 estresse foi desenvolvido mais rapidamente na resina fotopolimerizável e com valores mais altos do que nas resinas auto-polimerizáveis. Os autores concluíram que as resinas compostas fotopolimerizáveis geraram um estresse de contração mais alto do que as auto-polimerizáveis; as resinas fotopolimerizáveis resistiram melhor ao estresse inicial do que as auto-polimerizáveis; as resinas fotopolimerizáveis apresentaram menor capacidade de escoamento; a inclusão de porosidades no interior das resinas fotopolimerizáveis diminuiu e tornou mais lento o desenvolvimento do estresse. 
Em 1993, TUMENAS avaliou a efetividade de algumas técnicas de inserção e polimerização na redução da infiltração marginal em restaurações de Classe II com resina composta. Utilizou 20 pré-molares humanos extraídos, que receberam cavidades de Classe II ( $M$ e D), com suas paredes gengivais localizadas a $0,5 \mathrm{~mm}$ aquém da união cemento/esmalte. As restaurações foram realizadas pela técnica de inserção única, com e sem uso de cunha refletiva, e pela técnica de inserção incremental, também com e sem uso da cunha refletiva, e submetidas, posteriormente, à ciclagem térmica durante 15 dias, em água destilada, com variação de temperatura entre 5 e $55^{\circ} \mathrm{C}$, sendo que o último ciclo foi realizado com Rhodamina B a 0,1\%. A análise foi realizada por escores, aplicados por três examinadores, através de diapositivos obtidos utilizando-se uma câmera fotográfica acoplada a um microscópio óptico. A análise dos resultados permitiu concluir que: 1- As técnicas de inserção e polimerização utilizadas foram incapazes de bloquear totalmente a infiltração marginal; 2- Não houve diferença estatisticamente significante na infiltração marginal entre as técnicas de inserção e polimerização utilizadas; 3- Embora os resultados não tenham mostrado diferenças entre as diferentes técnicas de inserção e polimerização, o grupo restaurado pela técnica incremental e uso de cunha refletiva apresentou menores escores com relação à infiltração marginal cervical.

Em 1995, DERHAMl; COLI e BRÄNNSTROM, empregaram o método de penetração do corante para estudar a eficiência de dois sistemas de adesivos dentinários, que usavam ácido cítrico a 10\%, na prevenção da microinfiltração de cavidades de Classe II restauradas com resina composta. Investigaram a microinfiltração em restaurações similares, usando EDTA a 0,2\% no lugar do tratamento da superfície dentinária com os dois sistemas adesivos dentinários. Utilizando microscopia óptica de varredura, examinaram a morfologia das margens dentinárias cervicais, após o uso dos três condicionadores dentinários (10-3 conditioner, 10-20 conditioner e EDTA 0,2\%). As cavidades tratadas com EDTA 
mostraram resultados similares aos condicionadores dos sistemas adesivos e nenhuma das formas de tratamento preveniu microinfiltração nas restaurações de resina composta de Classe II .

Em 1995, DIETSCHI et al. realizaram um estudo "in vitro" para investigar o selamento e a adaptação marginal de duas técnicas de restauração com resina composta APH (Dentsply) (técnica direta com três direções de polimerização) e inlay indireto (Extraoral inlay system, Dentsply) e de duas formas de preparo gengival (com e sem bisel), relacionado com a localização e espessura do esmalte cervical. Foram confeccionadas cavidades ocluso-proximais em terceiros molares com as seguintes dimensões: $4 \mathrm{~mm}$ largura e $1,5 \mathrm{~mm}$ de profundidade. As diferentes extensões gengivais que determinaram a espessura do esmalte cervical foram de 0,5; 1,0 e 1,5 mm aquém da união cemento/esmalte, com e sem bisel gengival. Os outros limites, axial e oclusal, receberam bisel. 0 condicionamento ácido foi realizado com ácido fosfórico a $37 \%$ durante 30 segundos e as cavidades foram lavadas durante 30 segundos e secas durante 15 segundos. A parede pulpar foi protegida com cimento de hidróxido de cálcio (Dycal, Dentsply). O sistema adesivo Universal Bond 3 (Denstply) foi aplicado à cavidade e polimerizado por 30 segundos. 0 primeiro incremento de resina (1 $\mathrm{mm}$ de espessura) foi inserido e fotopolimerizado em direção apical; o segundo foi inserido pela parede vestibular e polimerizado em direção à cúspide; e o terceiro incremento, preenchendo a caixa proximal, foi polimerizado através da cúspide. Finalmente, a caixa oclusal foi restaurada em incrementos e cada um desses fotopolimerizado durante 40 segundos com posicionamento da luz por oclusal. Os resultados mostraram que quando a espessura do esmalte gengival era menor que $0,5 \mathrm{~mm}$, a restauração indireta deveria ser a opção do tratamento. Quando se toma a opção da restauração direta, deve-se fazer o bisel proximal se o esmalte gengival tem pelo menos $1.0 \mathrm{~mm}$ de altura. $\mathrm{Na}$ técnica indireta, o preparo com bisel proporciona um selamento marginal apropriado. A preparação sem bisel é apropriado para inlays, 
embora a qualidade marginal seja ligeiramente influenciada pela extensão gengival do esmalte residual.

Em 1995, KANCA e MIDDLEBURY estudaram o efeito do estresse da contração de polimerização na integridade marginal de restaurações de resina com margens em dentina. Foram preparadas cavidades de Classe $\mathrm{V}$ nas superfícies lingual e vestibular de 25 pré-molares humanos extraídos. 0 esmalte foi condicionado com ácido fosfórico a 32\% e tratado com o adesivo Scotchbond (3M de polimerização química). A resina fotopolimerizável Z-100 (3M) foi utilizada para restaurar os preparos vestibulares e a resina auto-polimerizável Clearfil FII (Kuraray), para os preparos linguais. As restaurações foram polidas, os ápices, selados e os dentes incluídos em corante por 24 horas para serem, posteriormente, seccionados e a penetração do corante medida com o auxilio de um microscópio. A resistência adesiva foi adicionalmente determinada na superfície de dentina de 20 molares humanos extraídos e montados em acrílico, aplicando-se 0 adesivo Scotchbond (3M) e resina Z100 (3M) em 10 dentes e resina Clearfil FII (Kuraray) nos demais. A dureza superficial da resina foi medida em onze intervalos de tempo dentro de um período de 24 horas, sendo que 3 amostras foram criadas para cada período de tempo. A resina fotopolimerizável alcançou 90\% da dureza máxima em 24 horas, apresentando uma polimerização mais rápida que a resina auto-polimerizável. A conclusão mais importante do autor foi que os resultados sugerem que a resina auto-polimerizável pode produzir menor estresse na interface dentina/restauração do que a resina fotopolimerizável, podendo ainda ajudar a manter o selamento marginal até quando colocadas com adesivos de menor resistência adesiva.

Em 1995, REEVES et al. estudaram a microinfiltração de três sistemas adesivos para determinar se dentes bovinos podem ser empregrados como substitutos dos dentes humanos em testes de microinfiltração. Os materiais 
avaliados foram Scotchbond Multipurpose (3M), Prisma Universal Bond 3 (Denstply) e All Bond 2 (Bisco), utilizados em combinação com a resina composta Prisma APH (Denstply). Sessenta restaurações de Classe V foram preparadas na união cemento/esmalte em 30 dentes humanos e 30 dentes bovinos. Os dentes restaurados foram armazenados em água destilada a $37^{\circ} \mathrm{C}$ durante 3 dias, termociclados a $4^{\circ} \mathrm{C}$ e $58^{\circ} \mathrm{C}$ por 100 ciclos e retornados para água destilada por mais 4 dias. Em seguida, foram protegidos com esmalte de unhas até $1 \mathrm{~mm}$ aquém da margem da restauração, colocados em solução de radioisótopo por 2 horas e seccionados e radiografados. A microinfiltração foi avaliada nas margens de esmalte e dentina e os resultados analisados através dos testes Mann-Whitney e Kruskal-Wallis. As margens gengivais foram comparadas com as margens incisais das restaurações para todos os materiais. Não houve diferença de infiltração entre as margens incisal e gengival para os dentes humanos, entretenato, nos dentes bovinos a infiltração foi maior na margem gengival do que na incisal. Não se apresentaram diferenças estatisticamente significantes na quantidade de microinfiltração entre 0 substrato humano e 0 bovino. Esses resultados sugerem que pode-se usar dentes bovinos como substitutos dos dentes humanos nos testes "in vitro" de microinfiltração.

Ainda em 1995, TJAN; KLOOSTER e TAN analisaram e compararam a infiltração marginal de restaurações de resina composta em cavidades de Classe $\mathrm{V}$, restauradas através de: 1) técnica incremental 2) um único incremento e 3) um único incremento com pressão exercida com uma matriz. As cavidades possuíam a margem gengival em dentina e foram restauradas empregando 0 adesivo dentinário Optibond (Kerr) e resina composta Herculite XRV (Kerr). O polimento foi realizado 48 horas após a restauração e os dentes foram termociclados em solução de fucsina básica a $0.5 \%$. A penetração do corante na margem oclusal e gengival foi avaliada em microscópio com aumento de 100X e categorizada em escores de $0-4$. Os autores concluíram que as margens oclusais mostraram menor 
infiltração que as margens gengivais $(p<0.05)$. A técnica incremental teve melhor performance que a técnica de um único incremento, com ou sem compressão da matriz $(p<0.05)$.

Em 1996, CARVALHO et al. revisaram os aspectos relacionados com a contração de polimerização e a influência do desenvolvimento e alívio do estresse nas restaurações de resina composta. A inserção de restaurações adesivas de resina composta dentro de cavidades gera uma competição entre as tensões geradas pela contração de polimerização e a força de adesão à estrutura dentária. Segundo os autores, em vários estudos publicados os valores do estresse de contração superaram a resistência de união entre resina e estrutura dentária. A contração de polimerização das resinas compostas gera tensões que podem romper a interface adesiva dente/restauração, sendo essa a maior causa de falhas marginais, com subseqüente microinfiltração. 0 grau de estresse desenvolvido, ou de tensões geradas, pode ser controlado através de: tipo de desenho cavitário (Fator-C); uso de bases de baixo módulo de elasticidade; técnica de inserção; tipo de resina composta (auto-polimerizável / fotopolimerizável); uso de sistemas adesivos mais resistentes aos efeitos da contração de polimerização e fenômeno de sorpção de água. É de suma importância clínica que o cirurgião-dentista conheça e entenda esses princípios para tentar contornar os efeitos adversos da contração de polimerização.

Em 1996, CORREA avaliou a influência da umidade superficial da dentina na infiltração marginal de restaurações adesivas, empregando o sistema restaurador adesivo Scotchbond Multipurpose (3M) / Z100 (3M). Para tanto, utilizou 50 pré-molares humanos extraídos e confeccionou preparos de Classe II MOD com ambas as paredes gengivais localizadas $1 \mathrm{~mm}$ além da união cemento/esmalte. Após lavar o condicionador ácido, e previamente à aplicação do sistema adesivo, a umidade remanescente nas cavidades foi tratada de diferentes 
formas: aplicação de jatos de ar durante 10 segundos (controle); aplicação de jatos de ar durante 3 segundos; emprego do papel absorvente e aplicação de jatos de ar durante 10 segundos, seguido de reumedecimento e emprego de papel absorvente. Em seguida, aplicou o "primer" e o adesivo do Sistema Scotchbond Multipurpose (3M) e as cavidades foram restauradas com resina Z100 (3M) pela técnica incremental direta. Os espécimes foram submetidos à termociclagem com temperaturas entre $5^{\circ} \mathrm{C} \pm 3$ e $55^{\circ} \mathrm{C} \pm 3$, com 15 segundos cada imersão, em um total de 500 ciclos. A seguir os espécimes foram imersos em uma solução de fucsina básica a $0,5 \%$, durante 24 horas. Posteriormente, foram seccionados no sentido mesio-distal, obtendo-se de 4 a 5 secções de cada espécime para se determinar os índices de infiltração marginal os quais foram atribuídos por três avaliadores previamente calibrados, através de um microscópio estereoscópico com aumento de 40X. A análise foi realizada por meio de escores, tornando possível concluir que: 1- Nenhum dos grupos experimentais foi capaz de bloquear totalmente a infiltração nas margens da dentina e/ou cemento; 2- Não houve diferença estatisticamente significante no grau de infiltração marginal ocorrida nos 5 grupos experimentais e, 3- 0 grupo onde as cavidades tiveram aplicação ostensiva de jatos de ar (10 segundos) apresentou maior porcentagem de índice máximo de infiltração marginal. Por outro lado, os grupos cujas cavidades permaneceram visivelmente úmidas antes da aplicação do "primer", apresentaram maior quantidade de índice zero de infiltração.

Em 1996, SÁBIO avaliou a infiltração marginal em margens de esmalte e dentina de cavidades de Classe $\mathrm{V}$ restauradas com resina composta fotopolimerizável ou auto-polimerizável. Molares humanos extraídos receberam cavidades de aproximadamente $3 \mathrm{~mm} \times 3 \mathrm{~mm} \times 3 \mathrm{~mm}$, nas faces vestibular e lingual, estando a parede gengival localizada aproximadamente $2 \mathrm{~mm}$ além da união amelocementária. As cavidades foram restauradas com as resinas compostas Herculite XRV, (Kerr) ou Adaptic, (Johnson \& Johnson) pela técnica de 
um único incremento. Metade da amostra foi restaurada com aplicação dos agentes adesivos (XR Primer/XR Bond, Kerr e ARM, Johnson \& Johnson) e metade sem a aplicação destes. Após acabamento e polimento imediatos com laminas de bisturi n. 12 e discos Sof lex (3M do Brasil), os dentes foram protegidos com a colocação de selantes em todos os sulcos oclusais dos molares e os ápices foram vedados com amálgama dental e cola de presa rápida. Finalmente, todos os espécimes foram protegidos com três camadas de esmalte de unha até uma distância de $2 \mathrm{~mm}$ aquém das margens da restauração. Os dentes foram imersos em solução de azul de metileno a $2 \%$ tamponado $(\mathrm{pH} 7.0)$ por 20 horas a $37^{\circ} \mathrm{C}$, lavados em água corrente durante uma hora, seccionados no sentido mesio-distal e as hemi-secções contendo as restaurações foram incluídas em resina acrílica. As restaurações foram seccionadas de maneira seriada, no sentido gengivo-oclusal e o grau de infiltração foi avaliado por escores (0-3). Os resultados demonstraram que a infiltração marginal foi total nas restaurações realizadas sem os respectivos agentes adesivos para as duas resinas compostas, em ambas as paredes. Os menores índices de infiltração marginal foram observados nas restaurações de resina composta Adaptic (Johnson \& Johnson), com a utilização do agente de união ARM (Johnson \& Johnson), em ambas as paredes cavitárias.

Em 1997, ALANI e TOH propuseram-se a realizar uma revisão de várias técnicas para estudar a infiltração marginal, a qual pode servir de guia para futuras investigações e/ou ajudar o clínico geral na avaliação dos trabalhos publicados. Os principais métodos para a deteç̧ão da infiltração marginal das restaurações são: infiltração de corantes orgânicos, agentes traçadores químicos, traçadores radioativos, utilização de bactérias, uso do ar comprimido, produção de cáries artificiais, análise através de ativação de nêutrons e condutibilidade elétrica. Os autores enunciaram as vantagens da técnica da penetração de corantes as quais são: ser detectável em concentração diluída, econômica e não tóxica. $E$ as 
desvantagens desse procedimento são: resultados subjetivos e demanda destruição dos espécimes. Os autores também estudaram a ciclagem mecânica como outro fator importante ao simular as condições orais e a influência da termociclagem nos resultados de avaliação da microinfiltração, haja vista a grande variedade das temperaturas utilizadas nos ciclos, duração e número dos mesmos, pode-se observar uma diversidade de trabalhos com resultados contraditórios, não existindo um consenso a respeito desses fatores. Os autores recomendaram que os dentes restaurados com resina compostas que vão ser submetidos a testes de microinfiltração sejam mantidos em água por 24 horas para permitir que a sorpção de agua ocorra primeiro. Concluíram que não existe nenhum método eficaz e seguro para detectar infiltração e sugeriram a utilização de agentes traçadores como um método confiável, considerando as desvantagens citadas.

Em 1997, BOUSCHLICHER, VARGAS e BOYER avaliaram a influência do tipo de resina composta, da intensidade de luz, do fator de configuração cavitária e da fotopolimerização com laser sobre a contração de polimerização em um modelo experimental de simulação do Fator-C. Foram utilizadas uma resina auto-polimerizável (Silar, 3M) e duas fotopolimerizáveis, uma híbrida (Z100, 3M) e outra de micropartícula (Silux, 3M). Foram testadas três diferentes intensidades de luz, os fatores de configuração cavitária (Fator-C) de 1.0, 3.0, 5.0 e 3 fontes de luz em 4 diferentes potências, incluindo 2 tipos de laser. A resina Z100 (3M) apresentou 0 valor mais alto de força de contração, seguida pelas resinas Silux $(3 M)$ e Silar (3M), as quais apresentaram a menor força de contração de polimerização. Os grupos com Fator- $\mathrm{C}=5.0$ e $\mathrm{C}=3.0$ apresentaram valores iniciais de força de contração semelhantes entre si e estatisticamente diferentes do grupo com Fator-C=1, pois a máxima força de contração de polimerização foi inversamente proporcional ao valor numérico do Fator- $\mathrm{C}(\mathrm{C}=5<\mathrm{C}=3<\mathrm{C}=1)$ e diretamente proporcional ao volume da resina composta utilizada nesse modelo dinâmico de medição. Embora o grupo com Fator $C=1.0$ tenha desenvolvido a 
menor contração inicial, este apresentou os valores mais altos de força de contração. A força máxima de contração ocorreu com a utilização do fotopolimerizador convencional quando comparado com os dois tipos de laser, que apresentaram valores mais baixos.

Em 1998, CARDOSO e VIEIRA avaliaram a capacidade de vedamento marginal proporcionado por três sistemas adesivos, em 45 dentes extraídos, os quais receberam cavidades de Classe II MOD restauradas com os sistemas adesivos: Scotchbond (3M); Scotchbond Multipurpose Plus (3M); Prime \& Bond 2.0 (Dentsply) e resina TPH (Dentsply). A parede gengival de uma das caixas proximais foi localizada $2 \mathrm{~mm}$ aquém da união amelocementária e a outra, $2 \mathrm{~mm}$ além desta. Os dentes foram termociclados em água durante uma semana, com variações de temperatura entre $5^{\circ} \mathrm{C}$ a $55^{\circ} \mathrm{C}$ e utilizou-se, no último dia, fucsina básica a $0,5 \%$. Os dentes foram lavados e secionados para se observar o grau de infiltração marginal e medir a microinfiltração através de escores (0-3). Os resultados indicaram melhor comportamento dos sistemas adesivos Scotch Bond Multipurpose Plus (3M) e Prime \& Bond 2.0 (Denstply), respectivamente para as cavidades com todas as paredes em esmalte e o sistema adesivo Prime \& Bond 2.0 (Denstply) para as cavidades com a parede gengival em dentina. 0 sistema adesivo Scotchbond (3M) apresentou o pior comportamento tanto em dentina quanto em esmalte.

Em 1998, CARVALHO dissertou sobre os fundamentos para aplicação clínica dos adesivos dentinários e sobre os princípios de adesão. Sobre adesão ao esmalte, descreveu morfologia, composição do substrato e como devem ser analisados esses fatores para o melhor aproveitamento da técnica. Sobre adesão à dentina, enfatizou a importância do conhecimento da morfologia do substrato, formação da smear layer e seu tratamento com os diferentes materiais, compatibilidade entre umidade e adesivos detinários de última geração, a 
diferença entre adesivos a base de álcool, acetona e a base de água. Discutiu também sobre o condicionamento ácido, o papel da água na manutenção da integridade estrutural da dentina desmineralizada e a aplicação correta do "primer" e do adesivo, questionando o que acontece quando existe excesso ou falta destes, ressaltando a importância da formação da camada híbrida e seu papel na manutenção da interface adesiva. Descreveu as últimas gerações de adesivos, concluiu que o sucesso das restaurações adesivas depende de um complicado, porém, interessante exercício de capacidade de análise e discernimento sobre 0 material e técnica disponíveis, fundamentados sempre no respeito às caraterísticas naturais dos substratos dentinários.

Em 1998, DAVIDSON discutiu aspectos referentes ao alívio do estresse da contração de polimerização e as principais formas de manipular ou controlar esse estresse: 1) o escoamento: as vezes podemos controlar a contração de polimerização pela própria seleção dos materiais e com uma criativa manipulação dos mesmos. Se uma restauração escoar e contrair-se mais ou menos livremente, o estresse da contração de polimerização será menor, o escoamento dos materiais é limitado quando estes estão dentro de uma cavidade e ocorre principalmente na fase pré-gel. Já na fase pós-gel, o endurecimento do material gera forças contrácteis, tornando-o rígido e resistente, devendo-se considerar que, nessa fase, a capacidade de escoamento decresce e o enrijecimento continua aumentando; 2) A elasticidade adicional: quando o estresse não é aliviado pelo escoamento e não se consegue controlar a contração, deve-se buscar outras soluções nas caraterísticas do material. Os materiais com baixa rigidez produzem menos estresse que outros com alta rigidez. Ao colocar uma camada de adesivo com carga ou "liner" na interface adesiva dente / restauração, esta pode contribuir para que exista uma maior mobilidade das superfícies aderidas e assim diminuir 0 estresse; 3) outras forma de controlar o estresse é a polimerização gradual por variação da energia de irradiação. A polimerização lenta ou gradual reduz 0 
estresse de contração de parede a parede, evitando desta forma a formação de tensões maiores que a resistência adesiva, tomando em consideração que a polimerização depende mais do tempo de exposição do que a intensidade de exposição; 4) também é importante a existência de certo grau de porosidades no material, já que isto pode permitir a expansão por sorção de água como compensação da contração de polimerização.

Em 1998, FERRARI; MANNOCCI e VICHI estudaram os sistemas adesivos de frasco único, comprovando que só quando eram aplicados no substrato dental condicionado existia o embricamento mecânico e quando eram aplicados no substrato não condicionado, não apresentaram formação da camada híbrida e os túbulos dentinários não eram completamente selados. O mecanismo de união dos sistemas adesivos à dentina e esmalte é basicamente micro-retentivo e, de fato, a formação da camada híbrida, os "tags" de resina e a formação das uniões laterais permitem uma forte união entre o substrato dental condicionado e a resina composta. Os autores relataram ainda as diferenças existentes entre os substratos dentários (esmalte, dentina e cemento) e a complexidade dessas variações dentro do mesmo substrato e de que forma afetam o selamento da restauração. Um outro ponto de discusão são as técnicas de inserção, onde abordaram as vantagens e desvantagens da técnica incremental sobre a de incremento único. Concluíram que fabricantes e pesquisadores têm tido muito progresso nos processos restauradores, porém é preciso pesquisar ainda mais.

Nesse mesmo ano, GORACCI, discutiu sobre os últimos avanços em adesão e comentou sobre os adesivos que removem a "smear layer", o que é também chamada de técnica de condicionamento total, criando uma união química e micromecânica na dentina, com a formação dos "tags" de resina. Esses dois mecanismos garantem a criação de uma camada elástica entre a restauração e 0 substrato dentário, criando uma ótima interface de união. Outro assunto de 
importância relevante é a umidade dentinária, uma vez que quando se resseca a dentina, as fibras colágenas se desidratam e colapsam, impedindo a união correta com adesivos. O perfeito condicionamento ácido, o tempo de aplicação e pH são outros aspectos importantes, juntamente com a polimerização gradual, a serem levados em consideração na produção de melhores restaurações de resina composta. Embora as diferenças entre os diversos tipos de substrato possam afetar a adesão, temos disponíveis muitos materiais e técnicas para nos ajudar a contornar os efeitos adversos das tensões geradas pela contração de polimerização das restaurações de resina composta.

Em 1998, VAN MEERBEEK et al. estudaram a performance clínica dos adesivos, catalogando-os pelo seu mecanismo de ação sobre a "smear layer" e enunciaram os parâmetros clínicos que podem afetar a performance clínica: fatores próprios do material, variedade do substrato, tamanho e forma da lesão, localização (mandíbula ou maxila), flexibilidade dos dentes, idade do paciente, umidade dentinária e conceitos de elasticidade adesiva. Os autores concluíram que a performance clínica dos adesivos atuais tem determinado uma significante melhora nas restaurações adesivas, as quais podem ser colocadas com uma alta probabilidade de sucesso clínico; os adesivos mais modernos são superiores a seus antecessores, especialmente em termos de retenção, a qual não é a principal causa de falha prematura da restauração; os adesivos mais recentes têm se mostrado menos sensíveis ao substrato dental e a outras variáveis; a maior desvantagem destes adesivos atuais é que nenhum deles é capaz de garantir o selamento hermético da restauração com margens livres de infiltração marginal.

Em 1998, VERSLUIS; TANTBIROJN e DOUGLAS analisaram o vetor de contração de polimerização das resinas auto e fotopolimerizáveis e, em particular, a crença de que as resinas compostas contraem-se em direção à fonte de luz. A contração direcionada para as margens melhora a qualidade marginal das restaurações de resina composta, embora a literatura não tenha conseguido 
suportar esta teoria. A determinação experimental dos padrões de contração de polimerização é muito dificil. Utilizaram a técnica do elemento finito para analisar a direção da contração de polimerização das resinas compostas. Os processos de polimerização têm duas fases, a pré-gel e a pós-gel, o estresse desenvolvido nas restaurações pode ser aliviado rapidamente pelo escoamento do material na fase pré-gel. 0 estresse residual surge depois da geleificação. Nas resinas fotopolimerizáveis a fase de gel varia profundamente de acordo com a intensidade de luz. Foram determinados o grau de conversão das resinas e as propriedades de contração em função do tempo. Os dados experimentais da determinação da transmisão de luz para diferentes materiais foram utilizados na simulação. A análise mostrou que a direção da contração não foi significantemente afetada pela orientação da fonte de luz, mas foi determinada principalmente pela superfície livre. Conseqüentemente, diferenças entre o padrão de contração das resinas auto e fotopolimerizáveis foi mínimo. Os autores concluíram que as resinas compostas não se contraem em direção à fonte de luz, mas que essa direção é predominantemente determinada pelo desenho cavitário (Fator-C) e a qualidade da adesão. Melhoras nas margens das restaurações só poderão ser alcançadas através da otimização de outros fatores, tais como os processos de polimerização, o procedimento de fotopolimerização e a qualidade de união. A direção do vetor de contração, em resposta ao posicionamento da fonte de luz, não parece ser um critério apropriado para otimizar a qualidade marginal das restaurações.

Em 1998, YAMAUTI avaliou a infiltração marginal em restaurações de resina composta, empregando diferentes técnicas de inserção e de fotopolimerização do material (variando a intensidade de luz ou a distância entre a fonte de luz e a superfície da restauração). Cavidades cilíndricas de Classe V, com $2.0 \mathrm{~mm}$ de diâmetro $\times 1.5 \mathrm{~mm}$ de profundidade foram preparadas nas raízes de terceiros molares humanos extraídos e restauradas com o sistema restaurador adesivo Single Bond (3M) / Z100 (3M), com aplicação da técnica incremental e 
técnica de um único incremento, através de 5 diferentes modos de fotopolimerização. Os espécimes foram submetidos à termociclagem (500ciclos, $5^{\circ} \mathrm{C}$ e $55^{\circ} \mathrm{C}$ com duração de 30 s cada ciclo) e imersos em solução de nitrato de prata a $50 \%$ para, posteriormente, serem secçionados em cortes de $0,5 \mathrm{~mm}$. 0 corte com maior infiltração linear, em milímetros, do corante foi escolhido para análise digitalizada no programa de computador. Os resultados demonstraram que as formas de inserção e de fotopolimerização são fatores que independem entre si, no que se refere a infiltração marginal. A técnica incremental demonstrou um menor índice de infiltração marginal em relação à técnica de um único incremento. O método de fotopolimerização gradual, partindo de uma intensidade de luz média, até atingir uma intensidade máxima, mostrou os menores índices de infiltração. A técnica de fotopolimerização gradual, de forma geral, apresentou baixos índices de infiltração em relação à técnica convencional.

Em 1999, BURKE et al. examinaram as razões dadas por dentistas e seus professores para fazer e substituir restaurações. Cada participante foi questionado a respeito das razões de colocar ou substituir restaurações. A idade do paciente, 0 tipo de restauração a ser substituída, o material, quando conhecido, foi anotado para cada restauração, assim como o tipo de material a ser colocado. As razões para fazer ou substituir restaurações foram principalmente cárie primária 41.3\%, cárie secundária $21,9 \%$, fratura dental $6,4 \%$, fratura ou degradação marginal $6,1 \%$ e defeitos não cariosos 5,8\%. Concluíram que a cárie secundária é a principal razão para substituir restaurações, independente do material. A análise estatística indicou que 0 amálgama proporciona significantemente maior longevidade às restaurações que as resinas compostas ou cimentos de ionômeros de vidro.

Em 1999, CHRISTENSEN discutiu as razões potenciais para a sensibilidade dental pós-operatória em restaurações de Classe II de resina composta e sugeriu métodos para a sua prevenção. Comentou a influência da 
falta de hidratação nos preparos dentários, já que a ausência de umidade prejudica a adesão dos novos sistemas adesivos. Um outro fator importante é a falta de selamento dos canalículos dentinários. Discutiu a capacidade do clínico geral em discernir sobre dessensibilização ou adesão. Concluiu, afirmando que a sensibilidade é um problema crônico, embora as pesquisas clínicas centralizem-se na microinfiltração e na resistência de união de agentes adesivos, e que são necessárias novas pesquisas para apoiar e/ou modificar o sucesso das técnicas clínicas.

Em 1999, YOSHIKAWA et al. avaliaram o efeito do Fator-C e a profundidade dentinária na resistência de união das resinas compostas à parede pulpar de cavidades de Classe I, com diferentes valores de Fator-C. Utilizando terceiros molares humanos extraídos sadios, lixaram o esmalte para expor uma dentina superficial (Fator-C=1, grupo I, controle) e, em seguida, confeccionaram cavidades de $3 \mathrm{~mm} \times 4 \mathrm{~mm} \times 2 \mathrm{~mm}$ na dentina profunda (Fator-C=3, grupo II). Para a obtenção do grupo III, as paredes laterais do preparo foram removidas, obtendo-se uma situação similar à do grupo I, porém em uma profundidade diferente, de modo a se obter a relação entre Fator- $\mathrm{C}=1$ e a dentina profunda. Posteriormente, as cavidades foram restauradas utilizando três sistemas adesivos (Clearfil Liner Bond II, Kuraray ; One Step, Bisco e Super-Bond D Liner, Sun Medical) e uma resina composta fotopolimerizável Clearfil Photo Posterior (Kuraray) e outra auto-polimerizável Concise (3M). Depois de 24 horas de armazenagem, os dentes foram seccionados e submetidos a testes de microtração na parede pulpar. Os resultados mostraram alta resistência adesiva na dentina superficial, Fator- $C=1$, para os três sistemas adesivos, porém, tanto o One Step (Bisco ) quanto o Super-Bond D Liner (Sun Medical) mostraram decréscimo na resistência adesiva para a situação dentina profunda / Fator-C=1. Quando o FatorC foi aumentado para 3 (grupo II), a resistência adesiva de todos os materiais caiu em média de 21 a 35\%, com diferença estatisticamente significante para Super- 
bond D Liner (Sun Medical). Os autores confirmaram a redução na resistência adesiva em função do aumento do Fator-C e da profundidade cavitária.

Em 2000, FRANCO e LOPES estudaram a influência da configuração cavitária (Fator-C) na microinfiltração de 4 materiais restauradores estéticos. Foram realizados preparos cavitários convencionais com dimensões de 2,9 mm de diâmetro e 1,5 mm de profundidade (Fator-C=5) e preparos cavitários em forma de pires (Fator-C<5), em sessenta pré-molares recém-extraídos. Estabeleceram os seguintes grupos: G-I (Z-100 / Single Bond, 3M), G-II (Freedom / Stae, SDI), G-III (Vitremer / Primer, (3M) e G-IV (Durafill / Durafill Bond, Kulzer), os quais foram restaurados seguindo as orientações de cada fabricante. A termociclagem dos espécimes foi realizada em solução aquosa de azul de metileno a $2 \%$, tamponada, com variação de temperatura entre $5^{\circ} \mathrm{C}$ e $55^{\circ} \mathrm{C}$, totalizando 70 ciclos de 6 minutos. Em seguida, foram seccionados e avaliados por dois examinadores, através de fotografias obtidas em esteromicroscópio. Os resultados mostraram que somente o sistema Durafill / Durafill Bond (Kulzer) sofreu influência significativa em função da configuração cavitária, ocorrendo menor infiltração nos preparos em forma de pires (Fator- $\mathrm{C}<5)$. 


\section{Proposição}

Avaliar a infiltração marginal em cavidades restauradas com resina composta em associação com um sistema adesivo.

Testar as hipóteses nulas de que:

1. A configuração cavitária não influencia os valores de infiltração marginal;

2. O modo de polimerização das resinas não influencia os valores de infiltração marginal.

3. A técnica de inserção não influência os valores de infiltração marginal. 


\section{Materiais e Métodos}

Com o objetivo de estudar os efeitos do modo de polimerização da resina, dois grupos de cavidades de $3 \mathrm{~mm}$ foram individualmente restaurados com resina fotopolimerizável (Z-100, 3M) e resina auto-polimerizável (Bisfil 2 B, Bisco), empregando-se o sistema adesivo Single Bond (3M) e uma técnica de incremento único. $\mathrm{O}$ quadro da composição dos materiais, fabricamte, número de lote, e data de validade se encontra em anexo n. 0.1

Para verificar o efeito da configuração cavitária e sua interação com o modo de polimerização, outros três grupos de cavidades de $6 \mathrm{~mm}$ foram restaurados com os mesmos materiais, empregando-se a técnica de um único incremento para dois grupos (resina fotopolimerizável e resina auto-polimerizável) e, para um grupo, a técnica incremental (2 incrementos de $3 \mathrm{~mm}$ cada) para a resina fotopolimerizável.

Neste estudo foram utilizados 60 incisivos bovinos, provenientes de um frigorífico da cidade de Bauru ${ }^{\mathbf{D}}$ que, imediatamente após a exodontia, foram armazenados em solução de Timol a 10\%, preparada pelo departamento de Bioquímica da Faculdade de Odontologia de Bauru, da Universidade de São Paulo. Posteriormente, os dentes foram submetidos a um processo de limpeza (raspagem corono-radicular) com instrumentos periodontais ${ }^{\boldsymbol{Q}}$ e lâminas de bisturi N..$^{0} 15^{\mathbf{B}} \mathrm{e}$ armazenados em uma solução antifúngica, antimicrobiana e antienzimática ${ }^{\boldsymbol{4}}$, a uma temperatura de $4 \pm 2^{\circ} \mathrm{C}$ (refrigerador doméstico), até 0 momento da confecção dos corpos de prova (Fig. 1).

1- Frigorifico Mondelli, Bauru, SP.

2- Curetas de Grace 13 e 14, 11 e 12, Hu Friedy, Chicago, II, EUA.

3- Lâminas de Bisturi n. ${ }^{0} 15$ Feather Safety Razor Co. Ltd.

4- Sodium Azide 100mM; Benzamidine HCL 50mM; ethyl-Maleimide $10 \mathrm{mM}$. 




Fig. 1 Dente bovino

Os dentes foram removidos da solução de armazenagem, lavados em água corrente, secionados perpendicularmente ao seu longo eixo no nível da união cemento / esmalte em uma máquina de corte ${ }^{\mathbf{0}}$, com o auxilio de um dispositivo de acrílico $^{2}$ para suporte (Fig. 2 e 3 ).

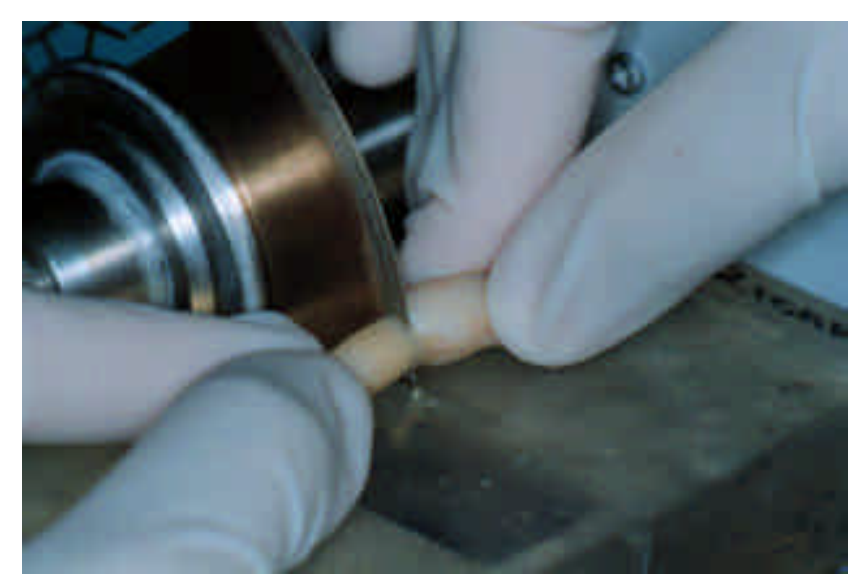

Fig. 2 Corte do dente bovino na máquina de corte com o dispositivo de acrílico

1. Máquina de corte Extec, Division of Excel Technologies Inc., Enfield, conecticut, USA.

2. Dispositivo de acrilico desenhado por Beltrão, $\mathrm{H}$. 


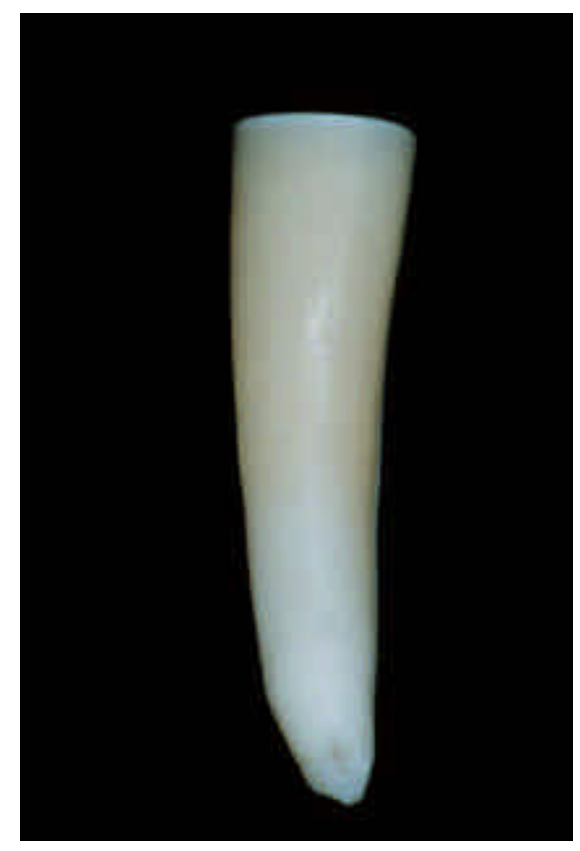

Fig. 3 Dente bovino secionado

O conduto radicular foi selado com cimento de ionômero de vidro ${ }^{\mathbf{D}}$ e o ápice com uma cola de presa rápida. ${ }^{2}$

A face vestibular da raiz foi cuidadosamente lixada na máquina politriz $^{\mathbf{3}}$, com lixas de água de granulação $220^{\boldsymbol{\Phi}}$, para remover o cemento e expor uma superfície plana de dentina.

\section{Preparo cavitário:}

Foram realizadas cavidades de Classe $\mathrm{V}$ com dimensões padronizadas em todos os dentes, utilizando-se uma caneta de alta rotação ${ }^{\boldsymbol{\sigma}}$, com broca carbide $\mathrm{N} .{ }^{\circ}$

1. Cimento de ionômero de vidro, Vidrion $C, S S$ White.

2. Superbonder, conteudo éster de cianoacrilato, Loctite Brasil Ltda.

3. Lixadeira e Politriz, Modelo PLF Fortel, Ind Brasileira.

4. Lixas de água, Norton, Brasil .

5. Caneta de Alta rotação, kavo do Brasil S.A., Joinville, Santa Catarina, Brasil. 
$56^{\mathbf{0}}$, sob adequada refrigeração (ar/água), sendo esta substituída a cada 5 preparos. Os preparos cavitários foram realizados na face vestibular das raízes dos dentes (terço cervical), aproximadamente $2 \mathrm{~mm}$ aquém da união amelocementária e dividas em dois grupos, com as seguintes dimensões: (Fig. 4)
A : $3 \mathrm{~mm} \times 3 \mathrm{~mm} \times 1,5 \mathrm{~mm}$ de profundidade.
B : $6 \mathrm{~mm} \times 3 \mathrm{~mm} \times 1,5 \mathrm{~mm}$ de profundidade.

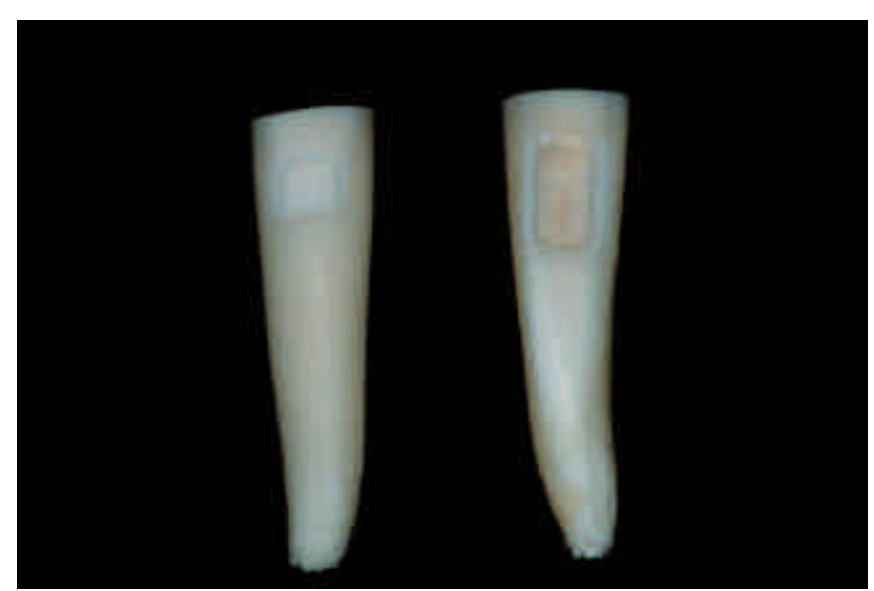

Fig. 4- Preparos cavitários: A - cavidade de $3 \mathrm{~mm}$ e B - cavidade de $6 \mathrm{~mm}$

Durante a confecção dos preparos, as dimensões foram aferidas com 0 auxílio de um paquímetro digital ${ }^{2}$. 0 acabamento das cavidades foi realizado com enxada N. ${ }^{\circ}{ }^{3}$

\section{Restaurações}

Imediatamente após a confecção de cada preparo, as restaurações foram realizadas alternadamente, segundo o tamanho da cavidade, a técnica de

1- Broca Carbide $N^{0} 57$, Jet Brand, Canada.

2- Paquímetro electrônico digital série 727 , Starret, Brasil.

3- Duflex-SS White, Ltda., Rio de Janeiro, RJ, Brasil. 
inserção e o tipo de resina auto-polimerizável $(A)$ ou fotopolimerizável $(F)$, dependendo do grupo de estudo.

\section{Técnica operatória}

Condicionamento ácido

O condicionamento ácido foi realizado com ácido fosfórico a 37\%, em gel (3M), durante 15 segundos (Fig. 5), seguido por lavagem com jato de água da seringa tríplice durante 30 segundos. A secagem das cavidades foi feita com o uso do papel absorvente (1) removendo os excessos, porém, deixando uma superfície de dentina úmida (Fig. 6).

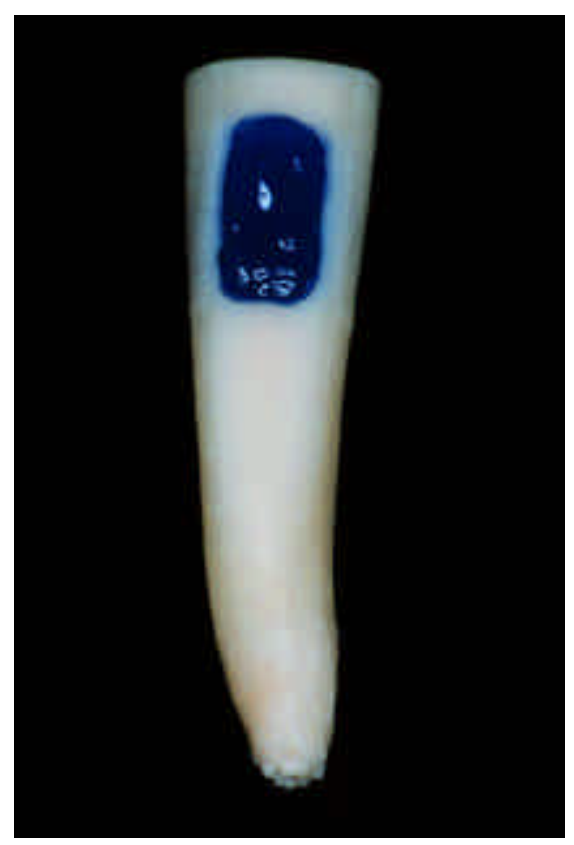

Fig. 5 Condicionamento ácido

1- Filtros de papel Melita Celupa, Guaíba, RS, Brasil 




Fig. 6 Secagem da cavidade com papel absorvente

\section{Aplicação do adesivo}

Foram aplicadas na cavidade 2 camadas do sistema adesivo Single Bond (3M), com pincel adaptado ao tamanho da cavidade (Fig. 7), até se observar uma superfície uniforme e brilhante (Fig. 8). Aplicou-se leve jato de ar por 10s, aguardando-se mais 20s para completar a evaporação do solvente. 0 adesivo foi fotopolimerizado por 10s, a uma distância menor que $5 \mathrm{~mm}$, com um aparelho fotopolimerizador (3M).2

1- Técnica preconizada por Carvalho, R.M.

2- Curing Light XL 3000, LR58141 CSA Standard, C 22.2, N. ${ }^{0} 125$, 3M Dental. 


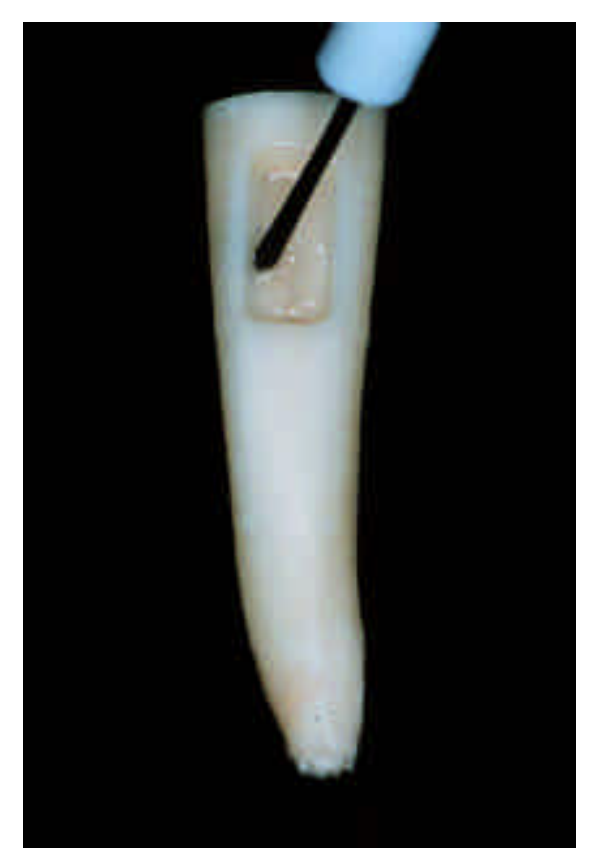

Fig. 7 Aplicação do sistema adesivo

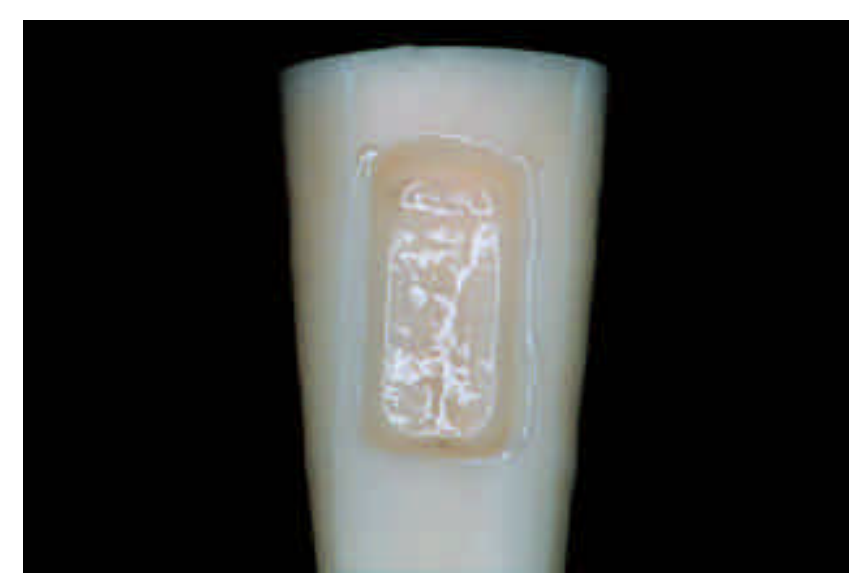

Fig. 8 Superfície brilhante após da aplicação do adesivo 
Restauração com resina composta

Foram realizados 5 grupos de estudo, com 12 corpos de prova cada, divididos de acordo com o material empregado, resina auto-polimerizável Bisfil 2B (Bisco) (Fig.9) e resina fotopolimerizavel Z-100 (3M) (Fig. 10), dimensão da cavidade e técnica de restauração.



Fig. 9 Resina Bisfil-2B, Bisco

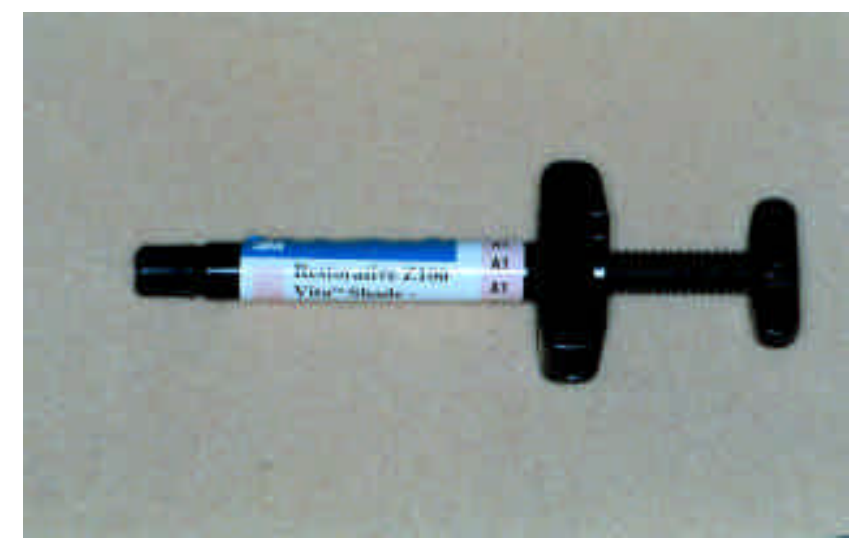

Fig. 10 Resina Z-100, 3M 
O quadro a seguir explica os procedimentos de acordo com o esquema experimental empregado.

Fig. 11 Quadro da divisão dos grupos de estudo, segundo o material empregado, dimensão das cavidades e técnica de restauração, com abreviações: A (autopolimerizável), $\mathrm{F}$ (fotopolimerizável),3 (3mm de comprimento) e 6 ( $6 \mathrm{~mm}$ de comprimento

\begin{tabular}{|ll|l|l|}
\hline \multicolumn{3}{|c|}{ Resina composta } & \multicolumn{2}{c|}{ Dimensão das cavidades } & \multicolumn{1}{c|}{ Técnica de restauração } \\
\cline { 1 - 2 } Bisfil 2B & A3 & $3 \mathrm{~mm} \times 3 \mathrm{~mm} \times 1,5 \mathrm{~mm}$ & \multirow{2}{*}{ Incremento único } \\
\cline { 1 - 2 } Bisfil 2 B & A6 & $6 \mathrm{~mm} \times 3 \mathrm{~mm} \times 1,5 \mathrm{~mm}$ & \\
\cline { 1 - 2 } Z-100 & F3 & $3 \mathrm{~mm} \times 3 \mathrm{~mm} \times 1,5 \mathrm{~mm}$ & \\
\cline { 1 - 2 } Z-100 & FU6 & $6 \mathrm{~mm} \times 3 \mathrm{~mm} \times 1,5 \mathrm{~mm}$ & \\
\cline { 1 - 2 } Z-100 & F6 & $6 \mathrm{~mm} \times 3 \mathrm{~mm} \times 1,5 \mathrm{~mm}$ & \multirow{2}{*}{ Técnica incremental } \\
\hline
\end{tabular}

Restauração de resina auto-polimerizável

A resina auto-polimerizável foi manipulada de acordo com as instruções do fabricante. Misturou-se porções iguais da pasta base com a pasta catalisadora em um bloco de papel, empregando uma espátula plástica ${ }^{\mathbf{D}}$. O material foi inserido com uma seringa Centrix ${ }^{2}$ na cavidade em um único incremento, acomodado com auxilio de espátula Thompson ${ }^{\mathbf{B}}$ e mantido sem perturbação durante 4 minutos. 1- Espátula plástica para cimentos, Pro, Medellín Colombia.

2- Espátula Thompson, Tactile tone GTX, \# 9, composite (C7), Dental MFG Co. USA.

3- Seringa Centrix, CE speed slot, Centrix Incorporated, USA. 
Restauração de resina fotopolimerizável

A resina fotopolimerizável foi inserida e acomodada na cavidade com espátula Thompson e fotopolimerizada diretamente com o feixe de luz perpendicular à superfície exposta da restauração, durante 40 segundos, com aparelho fotopolimerizador (3M) que emitia uma intensidade de luz entre 400 - 450 $\mathrm{mW} / \mathrm{cm}^{2}$, aferida com um radiômetro ${ }^{\mathbf{2}}$, antes de cada polimerização.

Restauração de resina fotopolimerizavel: técnica de um único incremento:

As restaurações foram realizadas preenchendo toda a cavidade com um único incremento.

Restauração de resina fotopolimerizavel: técnica incremental:

Essa técnica somente foi empregada nas cavidades de $6 \mathrm{~mm}$ de extensão. As restaurações foram realizadas inserindo a resina em dois incrementos (no sentido vertical) de $3 \mathrm{~mm}$ cada. 0 primeiro incremento foi sempre colocado na parede gengival, ou próximo a união amelocementária, e fotopolimerizado durante 40s (Fig. 12). O segundo incremento foi acomodado em seguida, preenchendo a parte restante da cavidade e também foi fotopolimerizado, por 40s (Fig. 13).

1- Espátula Thompson, Tactile tone GTX, \# 9, composite (C7), Dental MFG Co. USA

2- Curing Radiometer, Model 100 P/N 10503 serial n. ${ }^{0}$ 116095, Demetron Research Co. USA. 


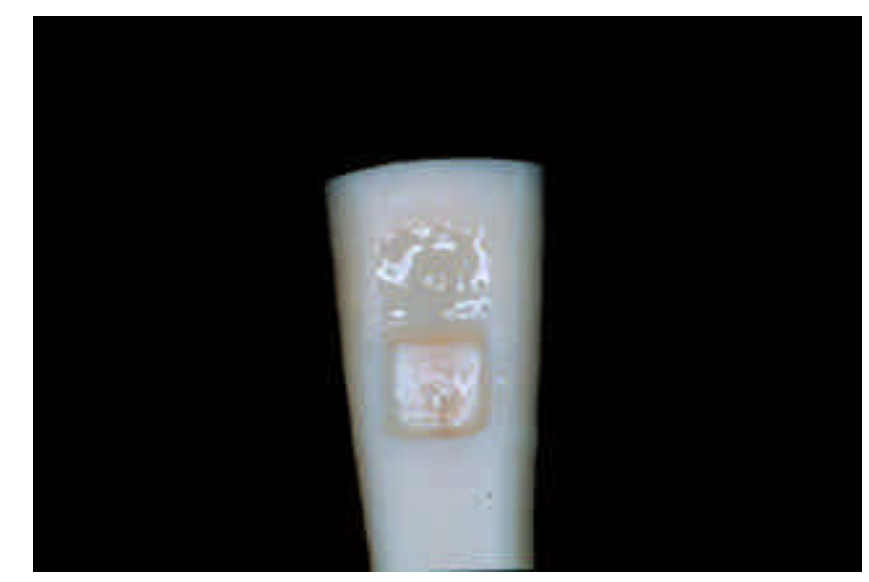

Fig. 12 Acomodação do primeiro incremento da técnica incremental

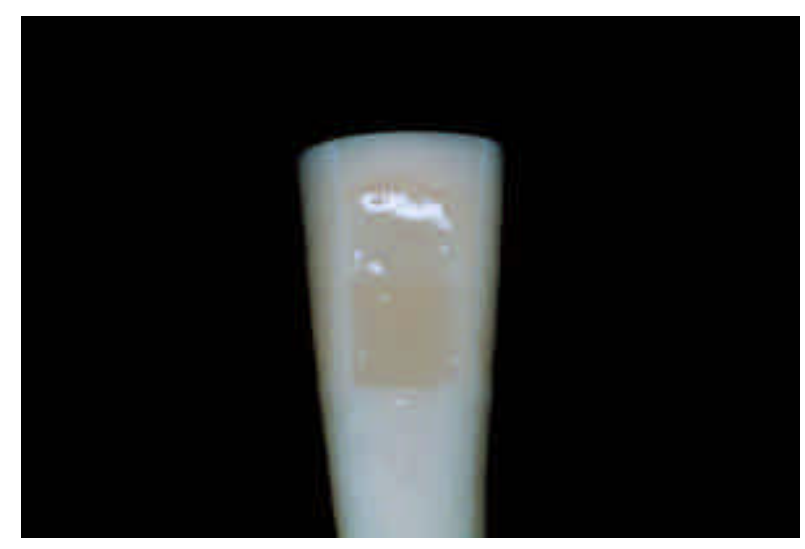

Fig. 13 Acomodação do incremento final da técnica incremental

\section{Acabamento imediato}

Os excessos das restaurações foram removidos com lâmina de bisturi $N{ }^{\circ}$ 15 , do centro da restauração para as margens. 


\section{Armazenagem}

Os espécimes foram armazenados submersos em água destilada, em uma estufa a $37^{\circ} \mathrm{C}$ durante 48 horas.

\section{Polimento}

Realizou-se o polimento com discos Sof-Lex XT Pop-on (3M) ${ }^{\mathbf{D}}$, iniciando-se com o disco de granulação média, depois fina e, finalmente, a ultrafina. Esse polimento foi realizado seguindo as instruções do fabricante, ou seja do centro da restauração para as margens.

\section{Teste}

Após o polimento, os dentes foram protegidos com duas camadas de esmalte de unhas 2 de secagem extra-rápida, 1 mm aquém das margens da restauração (Fig. 14). 


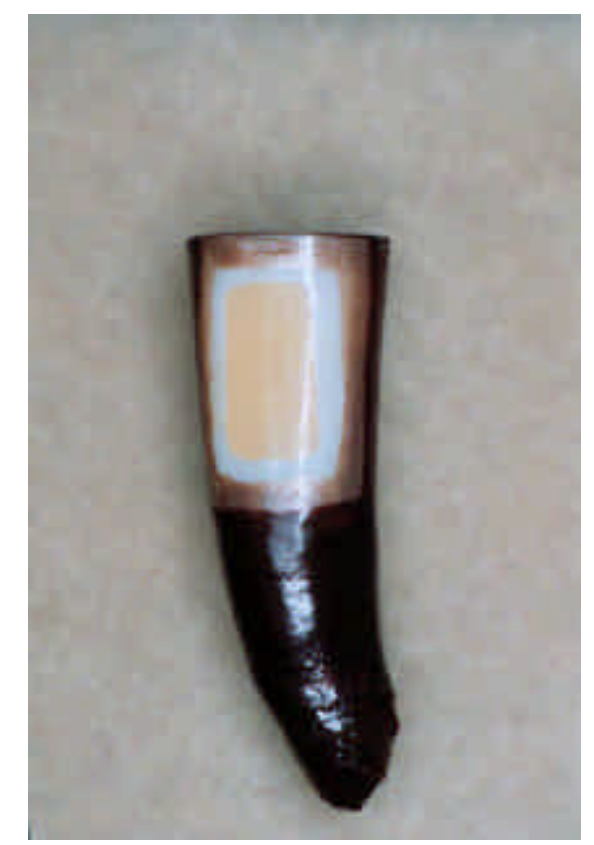

Fig. 14 Dente protegido com esmalte de unhas

Os dentes protegidos com esmalte de unhas foram submersos em solução aquosa de fucsina básica a $0.5 \%$ e armazenados em estufa a $37^{\circ}$ durante 4 horas.

Decorridas as 4 horas de imersão no corante, o esmalte de unhas foi retirado com uma espátula Lecron ${ }^{\mathbf{0}}$ e os dentes foram lavados em água corrente durante 1 hora.

Os espécimes foram secos ao ar ambiente e marcados com um pequeno corte perpendicular ao longo eixo dos dentes, no nível do terço apical da raiz, para identificar a localização da parede apical.

1- Espátula de Lecron, Duflex-SS White, Ltda., Rio de Janeiro, RJ, Brasil. 


\section{Inclusão e corte}

Após a secagem, os dentes foram incluídos em resina epóxica ${ }^{\mathbf{D}}$ com 0 auxílio de segmentos de tubos de PVC de $3 / 4$ de polegadas e comprimento de 3 $\mathrm{cm}$. Após a remoção dos espécimes incluídos nos tubos de PVC, os mesmos foram seccionados em várias secções de aproximadamente $1 \mathrm{~mm}$ cada, através da restauração, obtendo-se de duas a quatro secções por dente (Fig. 15).

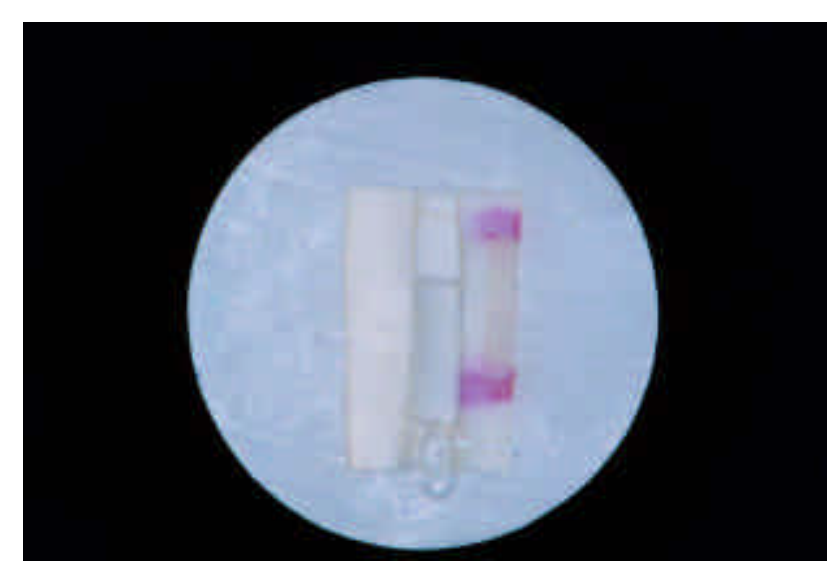

Fig. 15 Secções dos espécimes

\section{Análise dos índices de infiltração}

Cada secção foi digitalizada em um "scanner", junto com uma régua milimetrada, que, posteriormente, serviria para a calibração das medidas. As imagens obtidas das secções foram transportadas para o programa de computador Image Tool (UTHSCSA) e os índices de infiltração medidos em mm, em ambas as paredes, gengival e apical, das cavidades.

1- Resina Epoxi RD 6921, Lotes base 08611, catalisador 04709, Redefibra, Fiberglass, Itda. Brasil. 


\section{Análise estatística}

A secção que apresentou a maior extensão de infiltração em cada dente foi selecionada para análise estatística e as medidas de infiltração foram analisadas por ANOVA, considerando os fatores, parede cavitária, material restaurador e técnica de inserção. 0 nível de significancia estatística foi pré-estabelecido em $\alpha=5 \%$. 


\section{Resultados}

A análise estatística demonstrou não haver diferenças entre os valores médios de infiltração nas paredes gengival e apical $(p>0,05)$. Dessa maneira, esses valores foram agrupados para facilitar as análises posteriores entre os outros fatores em estudo.

Os valores de infiltração para a resina Z-100, respectivamente para as diferentes dimensões cavitárias (C3 e C6), foram virtualmente iguais $(p>0,05)$. A resina Bisfill-2B mostrou uma tendência de apresentar maiores valores de infiltração com o aumento da dimensão cavitária (C3 para C6), entretanto, essa tendência não foi confirmada estatisticamente $(p>0,05)$.

A resina Z-100, quando inserida pela técnica incremental nas cavidades C6, apresentou valores de infiltração ligeiramente maiores do que quando inserida em incremento único nas mesmas cavidades, embora esses valores não tenham sido estatisticamente significantes $(p>0,05)$.

Os valores médios de infiltração observados nas diferentes condições experimentais encontram-se apresentados na tabela 1 e fig. 15. Os valores individuais observados nos espécimes encontram-se descritos no quadro na seção de anexos. 
Tabela 1. Médias dos resultados da microinfiltração de acordo com os grupos, medidos em $\mathrm{mm} \pm$ S.D. (N)

\begin{tabular}{|c|c|c|c|}
\hline $\begin{array}{c}\text { Configuração } \\
\text { cavitária }\end{array}$ & $\begin{array}{c}\text { Z-100 } \\
\text { Incremento único }\end{array}$ & $\begin{array}{c}\text { Bisfil-2B } \\
\text { Incremento único }\end{array}$ & $\begin{array}{c}\text { Z-100 } \\
\text { Incremental }\end{array}$ \\
\hline C3 & $0.97 \pm 0.5^{\mathrm{a}}(12)$ & $0.88 \pm 0.5^{\mathrm{a}}(12)$ & -------------- \\
\hline C6 & $0.97 \pm 0.5^{\mathrm{a}}(12)$ & $1.20 \pm 0.3^{\mathrm{a}}(12)$ & $1.11 \pm 0.4^{a}(12)$ \\
\hline
\end{tabular}

Os valores identificados com letra sobrescrita iguais, não são estatisticamente diferentes $(p>0,05)$

Fig. 16 Gráfico dos resultados

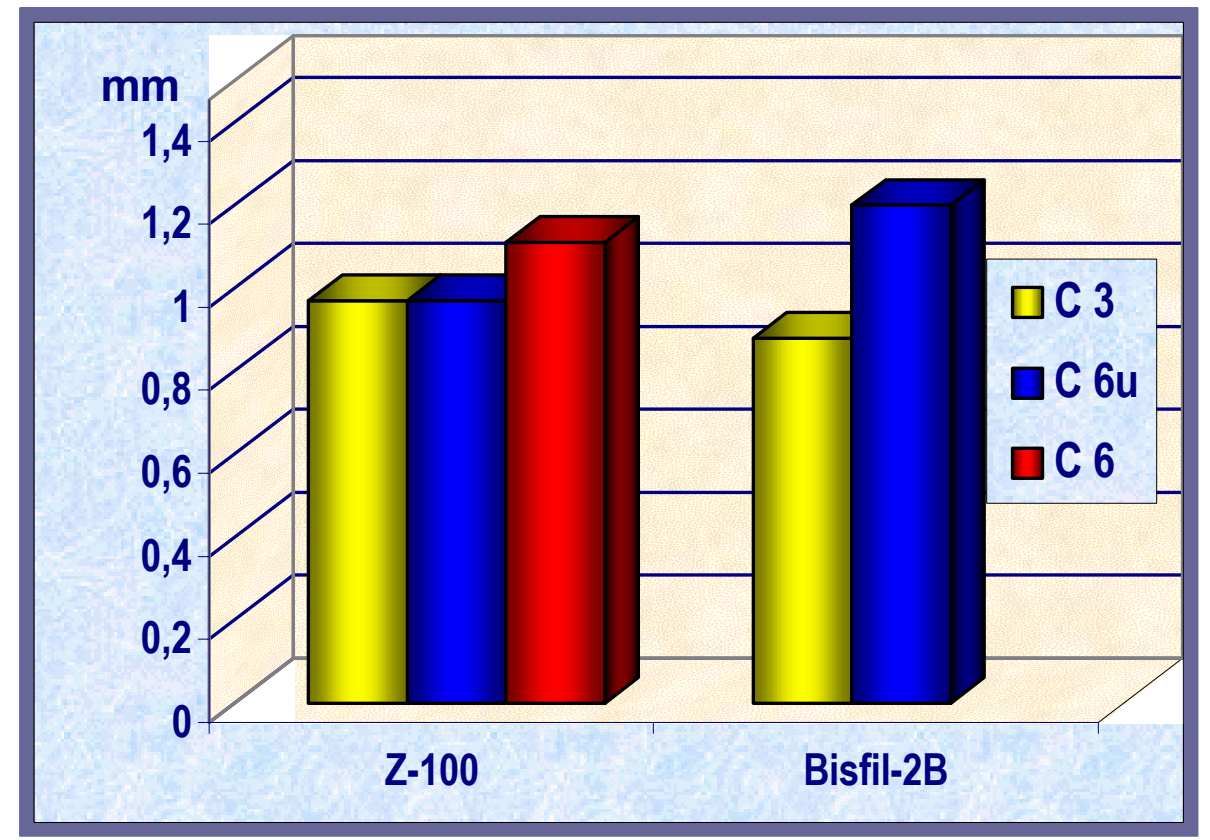




\section{Discussão}

A microinfiltração é definida como a passagem indetectável de bactérias, fluidos, moléculas ou íons entre as paredes cavitárias e o material restaurador2, 7. A microinfiltração na interface dente/restauração é considerada como o fator de maior influência na longevidade das restaurações dentais, podendo conduzir ao manchamento das margens da restauração, aceleração da ruptura das margens, cárie secundária, hipersensibilidade pós-operatória e desenvolvimento de patologias pulpares². Todas estas implicações clínicas podem ser o resultado da contração de polimerização e de diferenças de coeficiente de expansão térmica entre a estrutura dental e o material restaurador, pois estes podem exercer forças significativas na interface dente/material, resultando na falha de união e na formação de fendas 7 .

Há vários métodos de investigação disponíveis para se avaliar a microinfiltração marginal, concentrando-se na difusão de líquidos (corantes), penetração capilar, percolação marginal, infiltração micromarginal, diálise, trocas na pressão hidráulica ou gasosa e intercâmbio de fluidos ou íons entre a polpa e 0 meio oral. Dentre esses métodos, a visualização da interface é o método experimental mais antigo, utilizado por muitos autores $3,4,7,12,18,19,20,26,27,31,43,46,54$, ${ }^{58}$. para estudar a microinfiltração.

No presente estudo, utilizou-se dentes bovinos porque estes apresentam maior tamanho, o que serviria aos nossos propósitos de avaliar cavidades confeccionadas só em dentina, com medidas de $3 \times 6 \times 1,5 \mathrm{~mm}$. Cavidades com tais medidas se mostraram inviáveis de se confeccionar em dentes humanos. REEVES et al. ${ }^{49}$ propuseram-se a avaliar se o substrato de dentes bovinos poderia 
ser empregado como substituto dos dentes humanos em testes de infiltração marginal. Os resultados mostraram que não houve diferenças estatisticamente significantes entre o substrato bovino e o humano, o que permitiu concluir que os dentes bovinos podem ser substitutos de dentes humanos em testes de microinfiltração.

Para se avaliar a microinfiltração, várias substâncias podem ser utilizadas para corar as fendas marginais da interface adesiva dente/restauração. Em nosso trabalho, inicialmente, optamos por utilizar o azul de metileno a 2,0\%. Este corante, entretanto tem um $\mathrm{pH}$ ácido, portanto poderia criar a sua própria via de infiltração na estrutura dentária, desmineralizando-a. STARKEY, ANDERSON e PASHLEY56 em 1993, demonstraram que a solução azul de metileno pode ser tamponada, resultando em um pH neutro e permitindo que esta solução pudesse ser utilizada nos testes de microinfiltração. Porém, mesmo tamponada, esta solução mostrou-se inadequada no presente estudo. Ao analisarmos os espécimes do teste piloto, verificamos que a interface apresentava uma dupla coloração, confundindo a análise dos resultados. As colorações variavam entre 0 azul e o violeta, levando-nos a questionar se a solução de azul de metileno tamponada podia reagir com o agente adesivo Single Bond. Para testarmos essa hipótese fizemos um teste simples. Adicionamos algumas gotas da solução corantes a porções do adesivo, ora polimerizado, ora não polimerizado, e notamos que, geralmente quando 0 adesivo estava sem polimerização este reagia com a solução azul de metileno tamponada produzindo uma coloração violeta. Quando 0 adesivo era polimerizado antes da adição do corante, a coloração resultante permanecia azul. Considerando a possibilidade de uma possível reação química entre 0 corante e o adesivo, optamos por empregar uma solução aquosa de fucsina $0,5 \%$, tal como já utilizada em outros estudos $12,18,19,20,31,43,46,58$. 
A proposta deste estudo foi testar a microinfiltração imediata considerando os fatores relacionados exclusivamente com técnica de inserção, material e forma da cavidade. Por este motivo, os espécimes ficaram submersos em solução salina por apenas 48 horas, não sendo submetidos à ciclagem térmica. A razão para não empregarmos a termociclagem foi a de não poder refletir uma realidade clínica, já que as resinas não são bons condutores térmicos, e os períodos de imersão nas diferentes temperaturas, necessárias para que houvesse uma real troca térmica entre os espécimes e as soluções, seriam demasiadamente longas, as quis não refletem as situações clínicas de ingestão de alimentos em diferentes temperaturas. Poucos estudos atentam para este fato e creditam, equivocadamente, seus resultados aos efeitos de uma ciclagem térmica ineficaz em seu propósito51.

A contração de polimerização das resinas compostas é uma característica inerente do material, resultante do consumo das ligações duplas de carbono durante a polimerização e, por esse fato, inevitável nos materiais disponíveis atualmente. A contração de polimerização é o resultado da acomodação das moléculas em um espaço menor do que 0 requerido no estado liquido ${ }^{8}$. Esta contração de polimerização, quando restrita pela adesão às paredes cavitária, gera tensões que podem chegar a romper a interface adesiva. A competição entre a tensão de polimerização de resinas compostas e a união das mesmas às paredes da cavidade é uma das maiores causas de falha marginal que resulta em infiltração24, 13. A magnitude dessas tensões depende do tamanho e da forma da cavidade, fator descrito como fator de configuração cavitária ou Fator-C 22, 13. 0 Fator-C é definido pela formula:

$$
\text { Fator-C }=\frac{\text { Superfícies aderidas }}{\text { Superfícies não aderidas }}
$$


Segundo DAVIDSON22 (1986), as paredes aderidas são áreas de restrição de contração e as paredes livres são áreas que permitem o escoamento do material, relaxando as tensões de contração. De acordo com VERSLUIS et al. ${ }^{61}$ (1998), as resinas compostas contraem-se em direção às paredes às quais elas estão aderidas, portanto, quanto maior for a área de adesão, maior será a tendência dessa resina se contrair em direções antagônicas, gerando tensões nas respectivas interfaces adesivas, as quais não conseguem ser minimizadas pela reduzida área livre de escoamento. A relação entre a configuração cavitária e a conservação da união às paredes pode ser entendida no esquema proposto por DAVIDSON22 (1986):

$-$
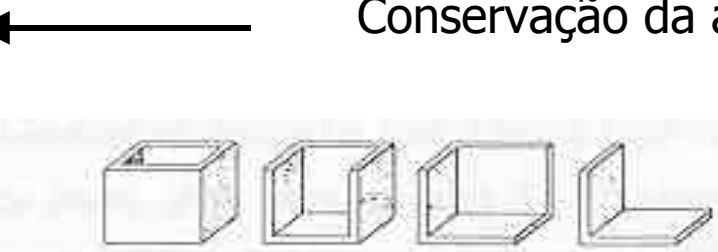

$+$

Conservação da forma anatômica


Fig. 17 Relação entre probabilidade de manutenção da adesão com a configuração cavitária

Em nosso trabalho, empregamos duas cavidades de forma semelhante, entretanto, a modificação de suas dimensões proporcionou uma diferente relação entre área aderida e área livre. Ao calcularmos o Fator-C para nossas cavidades encontramos os valores de $C=3$, para a cavidade de $3 \times 3 \times 1,5 \mathrm{~mm}$ (C3), e de $\mathrm{C}=2,5$, para a cavidade de $6 \times 3 \times 1,5 \mathrm{~mm}$ (C6). É interessante notar que a cavidade com menor dimensão apresenta um Fator-C maior. Quando analisamos os resultados obtidos com a resina fotopolimerizável (Z-100), notamos que os valores de infiltração foram virtualmente os mesmos para ambas as configurações cavitárias, nos permitindo assumir que o Fator-C não influenciou a qualidade de 
selamento marginal. Para a resina auto-polimerizável (Bisfil-2B), embora os valores não tenham sido significantes, percebemos que houve uma tendência da infiltração ser maior nas cavidades com o menor Fator-C. Esse fato poderia ser considerado contraditório se outros fatores não interagissem na determinação final da qualidade adesiva. Dentre os vários fatores a serem considerados, um de importância fundamental em nosso estudo está relacionado com o volume do material inserido nas cavidades. Embora a diferença entre os valores do Fator-C para ambas as cavidades seja mínimo, a diferença de volume de material inserido é duas vezes maior para as cavidades com menor Fator-C, ou seja, $13,5 \mathrm{~mm}^{3}$ para a cavidade C3 e $27 \mathrm{~mm}^{3}$ para a cavidade $\mathrm{C} 6$. Admite-se que um menor volume de material resulte em menor contração de polimerização, portanto, os efeitos das tensões de contração seriam menores em cavidades com menor volume de material ${ }^{5}$. Isto poderia explicar os resultados com a resina Bisfil-2B, entretanto, não explicaria a ausência desse efeito para a resina Z-100. Alguns autores acreditam que as tensões geradas pela contração de polimerização dependem da configuração cavitária e independem do volume do material 34 . Os fatores que regem a qualidade de selamento de uma restauração adesiva são diversos e podem estar relacionados com as características de polimerização do material e também com a eficácia de união aos tecidos dentários produzida pelo sistema adesivo. Alguns estudos demonstraram, por exemplo, uma relação positiva direta entre a quantidade de monômero diluído nas resinas com o tamanho das fendas marginais geradas pela contração de polimerização6. É possivel que a resina Bisfil-2B apresente uma composição que determine uma contração volumétrica proporcionalmente maior do que a resina Z-100, determinando diferenças observáveis de contração quando aplicada em maior volume. A incapacidade da resina Bisfil-2B de selar adequadamente as margens cavitárias pode, entretanto, ser explicada por achados recentes na literatura, que demonstram haver uma incompatibilidade química de união entre resinas auto-polimerizáveis e sistemas 
adesivos monocomponentes de características acídicas ${ }^{53}$. Se a incompatibilidade existe, um maior volume de material causaria maior contração, abrindo fendas marginais de maior magnitude e resultando em maior extensão de infiltração.

Partindo do princípio de que maiores volumes de material causam maiores tensões de contração, a técnica de inserção incremental tem sido sugerida por vários autores $5,10,15,16,20,22,28,36,41,43,45,46,47,48,55,58$, para otimizar o selamento marginal de restaurações adesivas. A técnica incremental pode reduzir a infiltração marginal das restaurações de resina composta, pois menores volumes de material


20, 59. Entretanto, DAVIDSON22 (1986) acrescenta que a técnica incremental somente se torna vantajosa nesse sentido, se cada incremento for aplicado de maneira a apresentar uma área de superfície aderida menor do que a área livre de escoamento, ou seja, com um Fator-C favorável. Nossos resultados mostraram que a inserção da resina Z-100 de forma incremental (2 incrementos) resultou em valores maiores de infiltração marginal, embora não significantes. Analisando separadamente os valores de infiltração para as paredes apical e gengival do grupo C6 (Z-100, incremental), encontramos que a média de infiltração na parede gengival foi de $0.97 \mathrm{~mm}$, enquanto que na parede apical foi de 1,25 mm. Em nossa técnica incremental, o primeiro incremento foi sempre aplicado na metade cavitária próxima à parede gengival. Nesse primeiro incremento, o Fator- $\mathrm{C}$ foi mais favorável, pois apresentava duas superfícies livres para o escoamento do material, enquanto que o segundo incremento apresentava somente uma superfície livre. Isso pode ter favorecido o relaxamento das tensões no primeiro incremento e resultado em melhor selamento da margem gengival. Embora a técnica incremental, por si só, possa não garantir uma redução significante das tensões de contração de polimerização, seu emprego é indicado para a confecção de todas as restaurações adesivas diretas, pois quando associada à aplicação estratégica de cada incremento dentro da cavidade, tem demonstrado ser um recurso seguro 
para minimizar a infiltração marginal $15,20,22,28,36,41,43,45,46,47,55,58,59$. Adicionalmente, a técnica incremental assegura a completa polimerização de toda a massa de material restaurador inserido na cavidade, fato esse que seria questionável em situações onde os incrementos ultrapassassem $2 \mathrm{~mm}$ de espessura.

Em nosso estudo, verificamos a influência do modo de polimerização das resinas compostas como um fator de modificação dos valores de infiltração marginal. Segundo FUSAYAMA 38 (1992), as resinas fotopolimerizáveis iniciam sua polimerização na camada superficial, próxima à fonte de luz. Posteriormente, as camadas mais profundas da resina se polimerizam em direção à camada superficial, gerando tensões de deslocamento na interface adesiva com as paredes cavitárias. A polimerização das resinas auto-polimerizáveis ocorre primeiramente junto às paredes cavitárias, devido a ausência de oxigênio nessa região e à maior temperatura, no caso de situações "in vivo". A polimerização inicial ocorrendo junto à interface adesiva, orienta o restante da polimerização para que ocorra nessa direção, evitando a criação de tensões de deslocamento das paredes cavitárias.

Auto-polimerizável

a.

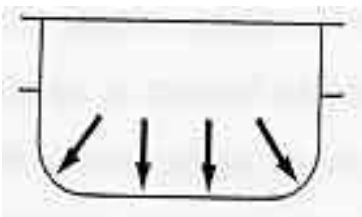

sem fenda
Fotopolimerizável

b.

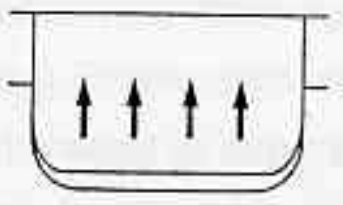

com fenda

Fig. 18 Esquema da relação do modo de polimerização das resinas e contração de polimerização 
Partindo desse conceito, alguns autores recomendam 0 uso de resinas auto-polimerizáveis para a restauração de dentes posteriores ${ }^{38,42}$, ou ainda, como base de restaurações de resina fotopolimerizável, favorecendo a união na interface adesiva com o substrato dentinário ${ }^{9}$. De fato, outros estudos demonstraram menores índices de infiltração marginal quando resinas auto-polimerizáveis foram empregadas em substituição às resinas fotopolimerizáveis ${ }^{52}$. 0 conceito proposto por FUSAYAMA ${ }^{38}$ (1992), foi recentemente contestado por VERSLUIS et al.61 (1998). Segundo estes autores, todas as resinas apresentam os vetores de contração direcionados para as paredes às quais elas estão aderidas, independente do seu modo de ativação. Sendo assim, a ocorrência de fendas ou falhas marginais está na dependência de outros fatores como módulo de elasticidade do material, Fator-C, qualidade da união, etc.

Em nossa concepção, a vantagem das resinas auto-polimerizáveis se encontra na dinâmica de sua polimerização. Segundo FEILZER, DE GEE e DAVIDSON32 (1988), a polimerização das resinas compostas pode ser dividida em duas fases, a fase pré-gel e a fase pós-gel. Na fase pré-gel, as ligações covalentes ainda não se estabeleceram, o material não se encontra rígido e 0 material é passível de escoamento. Uma vez atingida a fase de gel, os momentos seguintes do processo de polimerização (fase pós-gel) se caracterizam pela consolidação das ligações covalentes entre os radicais monoméricos, aumento significante da rigidez do material e incapacidade de escoamento. Portanto, quanto mais extensa for a fase pré-gel, maior será a capacidade do material de escoar e relaxar as tensões geradas pela polimerização ${ }^{10}$. Assim, as resinas auto-polimerizáveis, devido a sua reação de polimerização mais lenta, dispõe de uma fase pré-gel mais longa, permitindo um melhor escoamento do material e relaxando as tensões transferidas para a interface adesiva ${ }^{23}$. Nas resinas fotopolimerizadas, a velocidade da reação de polimerização pode ser controlada pela intensidade de luz com a qual se deflagra a reação. Por essa razão, alguns estudos têm recomendado que 
se inicie a fotoativação dessas resinas com uma intensidade de luz abaixo da ideal, com 0 intuito de retardar a reação e aumentar a tempo de duração da fase pré-ge|10, 21, 40, 44, 63. Esse procedimento parece ser viável para reduzir as tensões de contração e minimizar a ocorrência de infiltração marginal em restaurações de resina fotoativadas. A confirmação desse conceito não foi testada em nosso estudo, entretanto, consideramos que a incompatibilidade do sistema adesivo empregado com a respectiva resina auto-polimerizável (como já discutido anteriormente) possa ter prejudicado essa confirmação.

Em nosso estudo, optamos por realizar cavidades exclusivamente realizadas em substrato dentinário. Isso foi feito para eliminar a possível interferência de margens de esmalte, sobre as quais a adesão das resinas é superior e sua presença pode modificar os vetores de contração do material61. De fato, vários são os estudos que comprovam a eficiência da adesão ao esmalte como união ideal para garantir o selamento marginal de restaurações de resina composta 3, 12, 19, 24, 27, 31, 43, 47, 50, 54, 58, 62. A obtenção de um adequado selamento marginal de restaurações adesivas em dentina parece ser improvável, considerando o grande espectro de fatores que interferem nessa união. Sob 0 ponto de vista clínico, sugerimos que as restaurações adesivas sejam preferencialmente indicadas quando margens de esmalte estejam disponíveis na cavidade. Quando a situação clínica implicar na necessidade de se conseguir uma união à dentina, o profissional deve estar consciente de todos esses fatores que determinarão o sucesso de seu procedimento. Atenção especial deve ser dada a seleção de um bom sistema adesivo, à sua forma correta de aplicação e aos conceitos que regem a geração das tensões de contração de polimerização. Os incrementos devem ser aplicados de maneira a favorecer o escoamento do material (área aderida menor que área livre) e a fotoativação deve permitir uma extensão da fase pré-gel, sem entretanto, comprometer a conversão dos monômeros. Caso sua opção seja pelo emprego de resinas auto-polimerizáveis, 
considerar a eventual incompatibilidade dessas com os adesivos acídicos. Em última instância, sugerimos considerar o uso de bases ou forramentos de cimento de ionômero de vidro, o que, além de modificar a configuração cavitária permitindo um incremento da área de superfície de escoamento, permite um selamento marginal superior ao dos sistemas adesivos ${ }^{21,55}$. 


\section{Conclusões}

Verificando as hipóteses propostas, após a análise estatística dos resultados, podemos concluir que:

1- A configuração cavitária não influenciou os valores de infiltração marginal;

2- 0 modo de polimerização das resinas compostas não influenciou os valores de infiltração marginal.

3- A técnica de inserção não influenciou os valores de infiltração marginal.

As hipóteses antecipadas devem ser aceitas. 


\section{Anexos}

Anexo 1: Quadro da composição dos materiais empregados

\begin{tabular}{|c|c|c|c|c|}
\hline Material & Fabricante & Composição & N. ${ }^{0}$ Lote & Validade \\
\hline BisfilTM-2B & Bisco & $\begin{array}{c}\text { Catalisador: Bis-GMA, Glass frit, } \\
\text { silica, alumina. } \\
\text { Base: Bis-GMA, Glass frit, Sílica }\end{array}$ & $\begin{array}{c}059188 \\
079028\end{array}$ & $\begin{array}{c}2000-05 \\
2000-07\end{array}$ \\
\hline Etchant & $3 \mathrm{M}$ & Ac. Fosfórico en gel a 35\% & $7 \mathrm{JU}$ & $2000-04$ \\
\hline Single Bond & $3 \mathrm{M}$ & Etanol, HEMA, Bis-GMA, água, CQ & $7 \mathrm{BC}$ & $2000-11-16$ \\
\hline Z-100 & $3 \mathrm{M}$ & Matriz orgânica: Bis-GMA, TGMA; & 19970121 & $1999-10$ \\
& & Matriz inorgânica: Zircônio/Sílica & & \\
\hline
\end{tabular}


Anexo 2: Quando dos valores originais dos resultados de todos os grupos

\begin{tabular}{|r|r|r|r|r|r|r|r|r|r|}
\hline \multicolumn{1}{|c}{ F3 } & \multicolumn{4}{c}{ F6 } & \multicolumn{3}{c}{ Fu6 } & \multicolumn{3}{c|}{ A3 } \\
\hline Apical & Gengival & Apical & Gengival & Apical & Gengival & Apical & Gengival & Apical & Gengival \\
\hline 0 & 0 & 0,42 & 0,27 & 1,39 & 0,78 & 0,42 & 1,37 & 1,21 & 1,38 \\
\hline 1,44 & 0 & 0,95 & 1,37 & 0,38 & 0,27 & 0,52 & 0,43 & 0,77 & 0,85 \\
\hline 1,38 & 0,43 & 1,48 & 1,19 & 1,53 & 1,46 & 1,48 & 0,27 & 1,64 & 1,65 \\
\hline 1,56 & 1,57 & 1,04 & 0,86 & 1,48 & 1,1 & 0,93 & 0,51 & 1,44 & 0,62 \\
\hline 0,36 & 0,52 & 1,62 & 1,28 & 1,47 & 0 & 1,64 & 1,55 & 0,85 & 0,59 \\
\hline 1,16 & 1,17 & 1,38 & 0,17 & 1,52 & 0,62 & 0 & 0 & 1,5 & 1,5 \\
\hline 0,51 & 0,68 & 1,44 & 0,76 & 0,34 & 0,26 & 0,6 & 0,17 & 1,1 & 1,62 \\
\hline 0,82 & 1,36 & 1,44 & 0,93 & 0,61 & 0,26 & 1,53 & 0,51 & 1,37 & 1,45 \\
\hline 1,44 & 1,18 & 1,55 & 1,42 & 1,44 & 1,44 & 0,96 & 0,87 & 1,19 & 0,52 \\
\hline 1,56 & 0,69 & 0,76 & 1,56 & 1,53 & 1,56 & 0,6 & 1,13 & 1,44 & 1,44 \\
\hline 1,55 & 1,21 & 1,38 & 1,55 & 1,22 & 1,39 & 1,36 & 1,56 & 1,43 & 1,5 \\
\hline 1,38 & 1,36 & 1,55 & 0,34 & 0,77 & 0,68 & 1,38 & 1,5 & 0 & 1,45 \\
\hline
\end{tabular}




\section{Referências Bibliográficas}

1. ABDALLA, A.I.; DAVIDSON, C.L. Effect of mechanical load cycling on the marginal integrity of adhesive class I resin composite restoration. J. Dent., v.24, n.1-2, p.87-90, Jan./Mar. 1996.

2. ALANI, A.H.; TOH, C.G. Detection of microleakage around dental restorations: a review. Oper. Dent., v.22, n.4, p.173-85, July/Aug. 1997.

3. AL-HAMADANI, K.K.; CRABB, H.S.M. Marginal adaptation of composite resin. J. Oral Rehab., v.2, p.21-33, Jan. 1975.

4. ARAUJO, P.A.; ASMUSSEN, E. Effect of dentin adhesives on contraction of restorative resins in cavities surrounded by acid-etched enamel. Acta odont. scand., v.48, n.5, p.333-6, 1990.

5. ARAUJO, R, M;; da SILVA FILHO, F. P. M.; MENDES, A.J.D. Estudo da infiltração marginal em restaurações de resinas compostas para dentes posteriores. Efeito do material, preparo cavitário e condicionamento do esmalte a nível cervical. Rev. Odont. UNESP, v.19, n.1, p.191-201, 1990.

6. ASMUSSEN , E. Composite restorative resins. Composition versus wall to wall polymerization contraction. Acta odont. scand., v.33, n.6, p.337-44, 1975.

7. BAUER, J. G.; HENSON, J. L. Microleakage: a measure of the performance of direct filling materials. Oper. Dent., v.9, p.2-9, 1984.

* Normas recomendadas para uso no âmbito da Universidade de São Paulo, com base no documento "Referências Bibliográficas: exemplos", emanado do Conselho Supervisor do Sistema Integrado de Bibliotecas da USP, em reunião de 20 de setembro de 1990. 
8. BAUSCH, J. R. et al. Clinical significance of polymerization shrinkage of composite resin. J. prosth. Dent., v.48, n.1, p.59-67, July 1982.

9. BERTOLOTTI, R.L. Posterior composite technique utilizing directed polymerization shrinkage and a novel matrix. Pract. Period. Aesthet. Dent., v.3, n.4, p.53-8, June/July 1991.

10. BOUSCHLICHER, M.R.; VARGAS, M.A.; BOYER, D. B. Effect of composite type, light intensity, configuration factor and laser polymerization on polymerization contraction forces. Amer. J. Dent., v.10, n.2, p.88- 96, Apr. 1997.

11. BURKE, T.F.J. et al. Restoration longevity and analysis of reasons for the placement and replacement of restorations provided by vocational dental practitioners and their trainers in the United Kingdom. Quintessence Int., v.30, n.4, p.234-42, Apr. 1999.

12. CARDOSO, M,; VIEIRA, L.C.C. Infiltração marginal em cavidades classe II MOD em pré-molares. Rev. Ass. paul. cirurg. Dent., v.52, n.1, p.65-9, jan./fev. 1998.

13. CARVALHO, R.M. et al. A review of polymerization contraction: the influence of stress development versus stress relief. Oper. Dent., v.21, n.1, p.17-24, Jan./Feb. 1996.

14. CARVALHO, R.M., Adesivos dentinários, fundamentos para aplição clínica. RDR., v.1, n.2, p.62-96, abril, maio, junho 1998 
15. CHEUNG, G.S.P. Reducing marginal leakage of posterior composite resin restorations: a review of clinical techniques. J. prosth. Dent., v.63, n.3, p.286-8, Mar. 1990.

16. CHOHAYEB, A.A.; EICHMILLER, F.C. RUPP, N.W. Factors affecting microleakage of composite restorations, J. dent. Res., v.69, p.128, Mar. 1990. Special issue. / Abstract n.160/.

17. CHRISTENSEN, G.J. Prevenindo a sensibilidade nas restaurações de classe II em resina composta, JADA-Brasil, v.2, n.1, p.40-1, jan./fev. 1999.

18. CORREA, I.L.V. Influência na infiltração marginal de diferentes formas de tratamento da umidade em cavidades restauradas com Scotchbond multi-uso / Z-100. Bauru, 1996, 140p. Dissertação (Mestrado) - Faculdade de Odontologia de Bauru, Universidade de São Paulo.

19. CRIM, G. A. Influence of bonding agentes and composites on microleakage. J. prosth. Dent., v.61, n.5, p.571-4, May 1989.

20. CRIM, G.A. Microleakage of three resin placement techniques. Amer. J. Dent., v.4, n.2, p.69-72, Apr. 1991.

21. DAVIDSON, C.L. Handling of polymerization stresses in composite restorations, In: INTERNATIONAL SYMPOSIUM RECONSTRUCTIONS WHIT CARBON FIBER POSTS AND THE ADHESIVE SYSTEMS TODAY, 2., S. Margherita Ligure, 1998. Proceedings. Milano, Hippocrates Edizioni Medico Scientifiche, p.22-5. 
22. DAVIDSON, C.L. Resisting the curing contraction with adhesive composites. J. prosth. Dent., v.55, n.4, p.446-7, Apr. 1986.

23. DAVIDSON, C.L.; DE GEE, A.J. Relaxation of polymerization contraction stresses by flow in dental composites. J. dent. Res., v.63, n.2, p.146-8, Feb. 1984

24. DAVIDSON, C.L.; DE GEE, A.J..; FEILZER, J. A. The competition between the composite-dentin bond strength and the polymerization contraction stress. J. dent. Res., v.63, n.12, p.1396-9, Dec. 1984.

25. DAVIDSON, C.L.; FEILZER, J. Polymerization shrinkage and Polymerization shrinkage stress in polymer-based restoratives. J. Dent., v.25, n.6, p.43540, Nov. 1997.

26. DERHAMI, K.; COLI, P.; BRANNSTRÓM, M. Microleakage in class 2 composite resin restorations. Oper. Dent., v.20, n.3, p.100-5, May/June 1995.

27. DIETSCHI, D. et al. Marginal adaptation and seal of direct and indirect class II composite resin restorations: an in vitro evaluation. Quintessence Int., v.26, n.2, p.127-38, Feb. 1995.

28. EAKLE, W.S.; ITO, R.K,; Effect of insertion technique on microleakage in mesio-occluso-distal composite resin restorations. Quintessence Int., v.21, n.5, p.369-74, May 1990.

29. EICK, J. D.; WELCH, F. H. Polymerization shrinkage of posterior composite resins and its possible influence on postoperative sensitivity. Quintessence Int., v.17, n.2, p.103-11, Feb. 1986. 
30. ERICSON, D.; DÉRAND, T. Reduction of cervical gaps in class II composite resin restorations. J. prosth. Dent., v.65, n.1, p.33-37, Jan. 1991.

31. ESPINOSA, J.C.C. Avaliação da microinfiltração em restaurações mistas de classe V. Influência da contração de polimerização da resina composta, associada ao desenho cavitário, ao tratamento da superfície do cimento de ionómero de vidro e à ciclagem térmica. Bauru, 1991. 201p. Dissertação (Mestrado) - Faculdade de Odontologia de Bauru, Universidade de São Paulo.

32. FEILZER, A.J.; DE GEE, A.J..; DAVIDSON, C.L. Curing contraction of composites and glass ionomer cements. J. prosth. Dent., v.59, n.3, p.297300, Mar. 1988.

33. FEILZER, A.J.; DE GEE, A.J..; DAVIDSON, C.L. Increased wall-to wall curing contraction in thin bonded resin layers. J. dent. Res., v.68, n.1, p.48-50, Jan. 1989.

34. FEILZER, A.J.; DE GEE, A.J. ; DAVIDSON, C.L. Setting stress in composites resin in relation to configuration of the restoration. J. dent. Res., v.66, n.11, p.1636-9, Nov. 1987.

35. FEILZER, A.J.; DE GEE, A.J. ; DAVIDSON, C.L. Setting stresses in composites for two different curing modes. Dent. Mat., v.9, n.1, p.2-5, Jan. 1993.

36. FERRARI, M.; MANNOCCI, F. VICHI, A. Semplification of restorative procedures: an overview. In: INTERNATIONAL SYMPOSIUM RECONSTRUCTIONS WHIT CARBON FIBER POSTS AND THE 
ADHESIVE SYSTEMS TODAY, 2., S. Margherita Ligure, 1998. Proceedings. Milano, Hippocrates Edizioni Medico Scientifiche, p.41-3.

37. FRANCO, E.B.; LOPES, L.G. Influência da configuração cavitária na microinfiltração de materiais restauradores estéticos. Brazilian oral Rev., v.14, suplemento, p.76, 2000.

38. FUSAYAMA, T. Indications for self-cured and light-cured adhesive composite resins. J. prosth. Dent. v.67, n.1, p.46-51, Jan. 1992.

39. GOLDMAN, M. Polymerization shrinkage of resin based restorative material. Aust. dent. J., v.28, n.3, p.156-61, June 1987.

40. GORACCI, G. The latest discoveries in adhesion: recent studies. In: INTERNATIONAL SYMPOSIUM RECONSTRUCTIONS WHIT CARBON FIBER POSTS AND THE ADHESIVE SYSTEMS TODAY, 2., S. Margherita Ligure, 1998. Proceedings. Milano, Hippocrates Edizioni Medico Scientifiche, p.36-40.

41. HASSAN, $K$. et al. A modified incremental filling technique for class II composite restorations. J. prosth. Dent., v.58, n.2, p.153-6, Aug. 1987

42. KANCA, J.III.; MIDDLEBURY, C. T. Autocured vs. light-cured composites: rate of polymerization effect on dye penetration. J. dent. Res., v.74, p.150, 1995. Special issue. /Abstract n.1111/.

43. KOENIGSBERG, S.; FUKS, A.; GRAJOWER, R. The effect of three filling techniques on marginal leakage around class II composite resin restoration in vitro. Quintessence Int., v.20, n.2, p.117-21, Feb. 1989. 
44. LEAL, F.R.; BOUSCHLICHER, M.R. Microleakage in class V restoration using varying power densities and duration. J. dent. Res., v, 79, p.535, 2000, Special issue. /Abstract n. 3132.

45. LUTZ, F.; KREJCI, I.; OLDENBURG, T. R. Elimination of polymerization stresses at the margins of posterior composite resin restoration: a new restorative technique. Oper. Dent., v.17, n.12, p.777- 84, Dec. 1986.

46. NEIVA, I.F. et al. An in vitro study of the effect of restorative technique on marginal leakage in posterior composites. Oper. Dent., v.23, n.6, p.282-9, Nov./Dec. 1998.

47. PASCOTTO, R.C. Avaliação da infiltração marginal em nível de esmalte e cemento em cavidades de classe II MOD restauradas com resina composta pela técnica incremental direta e com incrustações de resina composta e de porcelana. Bauru, 1991, 142p. Dissertação (Mestrado) Faculdade de Odontologia de Bauru, Universidade de São Paulo.

48. POLLACK, B. Composite resin fundamentals and techniques restorations. N.Y. St. dent. J., v.53, n.5, p.25-7, May 1987.

49. REEVES,G.W. et al. Microleakage of new dentin bonding systems using human and bovine teeth. Oper. Dent., v.20, n.6, p.230-5, Nov./Dec. 1995.

50. RETIEF, H. D. Are adhesive techniques sufficient to prevent microleakage? Oper. Dent., v.12, p.140-5, 1987. 
51. ROSSOMANDO, K.J.; WENDT, S.L. Jr. Thermocycling and dwell times in microleakage evaluation for bonded restorations. Dent. Mat., v.11, n.1, p.47-51, Jan. 1995.

52. SÁBIO, S.S. Avaliação da infiltração marginal de restaurações com resina composta em função do tipo de ativação. Bauru, 1996, 119p. Dissertação (Mestrado) - Faculdade de Odontologia de Bauru, Universidade de São Paulo.

53. SANARES, et. al. chemical-cured composite weaken bonding of adhesive by surface interaction J. dent. Res., v, 79, p.356, 2000, Special issue. IAbstract n. 1700.

54. SILVA E SOUZA, M.H.Jr. et al. Avaliação da infiltração marginal em esmalte e cemento em cavidades de classe II MOD restauradas com cinco sistemas adesivos, Rev. Odont. USP, v.5, n.2, p.140-5, jul./dez. 1991.

55. SMITH, C.D.; CAUGHMAN, W.F. The effects of composite polymerization shrinkage on intercuspal distance. J. dent. Res., v.67, n.1, p.221, Jan./Apr. 1988. /Abstract n.864/.

56. STARKEY, D.L.; ANDERSON, R.W.; PASHLEY, D.H. An evaluation of the effect of methylene blue dye pH on apical leakage. J. Endod., v.19, n.9, p.435-9, Sept. 1993.

57. SUH, B. et al. The effect of total energy imput on physical properties of restorative composites. J. dent. Res., v.78, p.370, Mar. 1999. Special issue,/ Abstract n.2117. 
58. TJAN A.H.L.; KLOOSTER, J.; TAN, D.E. Microleakage of class $V$ composite restorations using various placement methods, J. dent. Res., v.74, p.494, June 1995. Special issue. /Abstract n.748/.

59. TUMENAS, I. Avaliação da infiltração marginal em cavidades de classe II restauradas com resina composta em função de diferentes técnicas de inserção e polimerização: estudo in vitro. Bauru, 1993. 101p. Dissertação (Mestrado) -Faculdade de Odontologia de Bauru, Universidade de São Paulo.

60. VAN MEERBEEK, B. et al. The clinical performance of adhesives. J. Dent., v.26, n.1, p.1-20, Jan. 1998.

61. VERSLUIS, A.; TANTBIROJN, D.; DOUGLAS, W.H. Do dental composites always shrink toward the light? J. dent. Res., v.77, n.6, p.1435-45, June 1998.

62. WELSH, E.L.; HEMBREE, J.H.Jr Microleakage at the gingival wall with four class $\mathrm{V}$ anterior restorative materials. J. prosthet. Dent, v.54, n.3, p.370-2, Sept. 1985.

63. YAMAUTI, M. Avaliação da infiltração marginal em restaurações de resina composta empregando-se diferentes técnicas de inserção e de ativação da polimerização do material. Bauru, 1999, p.141. Dissertação (Mestrado) - Faculdade de Odontologia de Bauru, Universidade de São Paulo. 
64. YOSHIKAWA, T. et al. Effects of dentin depth and cavity configuration on bond strength. J. dent Res., v.78, n.4, p.898-905, Apr. 1999. 


\section{Abstract}

Cavity configuration and mode of cure have been reported to affect bonding of resin to cavity walls. This study investigated the microleakage in class $\mathrm{V}$ resin restoration. Cavities measuring either $6 \mathrm{~mm}$ (C 6$)$ or $3 \mathrm{~mm}$ (C 3) long by $3 \mathrm{~mm}$ wide and $1.5 \mathrm{~mm}$ deep were cut in the roots of bovine teeth. The cavities were bonded with Single Bond and restored with either Z-100 or Bisfil-2B by using either bulk or incremental filling techniques. The restoration teeth were stored for $48 \mathrm{hrs}$ in water at $37^{\circ} \mathrm{C}$, covered with nail varnish up to $1 \mathrm{~mm}$ from the margins and immersed in $0.5 \%$ fucsin for $4 \mathrm{hrs}$. The restorations were sliced along the long axis and the degree of leakage (in $\mathrm{mm}$ ) determined by image analysis. The highest leakage for tooth was used for the calculations $(\mathrm{N}=24)$ :

\begin{tabular}{|c|c|c|c|}
\hline Cavity & Z-100-Bulk & Z-100-Incremental & Bisffl-2B-Bulk \\
\hline C 3 & $0.97 \pm 0.5^{a}$ & ------ & $0.88 \pm 0.5^{a}$ \\
\hline C 6 & $0.97 \pm 0.5^{a}$ & $1.11 \pm 0.4^{a}$ & $1.20 \pm 0.3^{a}$ \\
\hline
\end{tabular}

Two-way ANOVA showed that there was no significant influence or interaction between the factors (p.0.05). All filling techniques showed some degree of leakage and there was no statistically significant difference between gingival and apical walls $(p>0.05)$. microleakage was not affected by either configuration or mode of cure in this study. 